Universidad de Lima

Escuela de Posgrado

Maestría Tributación y Política Fiscal

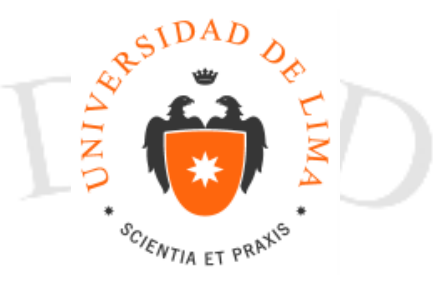

\title{
LA PRESCRIPCIÓN TRIBUTARIA COMO LÍMITE TEMPORAL A LA FACULTAD DE FISCALIZACIÓN
}

Trabajo de investigación para optar el Grado Académico de Maestro en Tributación y Política Fiscal

\section{Juan Alberto Garret Vargas}

Código 20132475

Lima - Perú

Mayo, 2015 


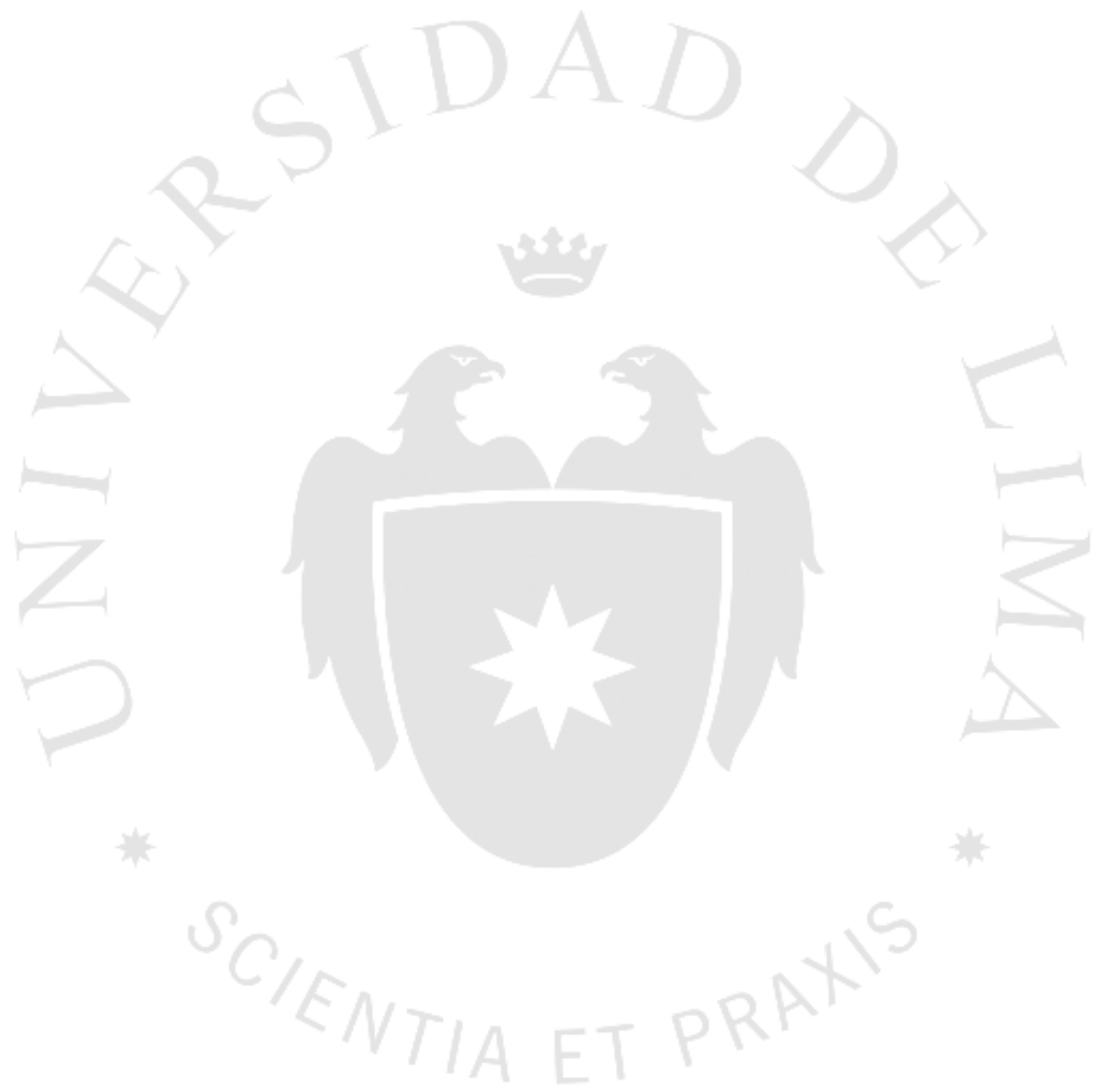




\section{LA PRESCRIPCIÓN TRIBUTARIA COMO LÍMITE TEMPORAL A LA FACULTAD DE FISCALIZACIÓN}




\section{TABLA DE CONTENIDO}

INTRODUCCIÓN .$v i$

\section{CAPÍTULO I: ASPECTOS BÁSICOS DE LA FACULTAD DE FISCALIZACIÓN Y}

DE LA PRESCRIPCIÓN

\section{.1}

1.1. La facultad de fiscalización de la Administración Tributaria.- ............................1

1.2. La determinación de la obligación tributaria.-...............................................11

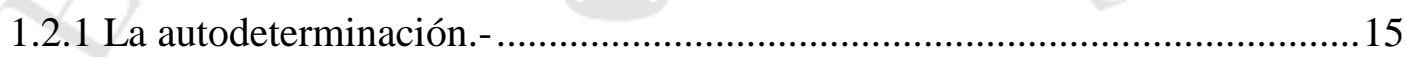

1.2.2. Determinación por parte de la Administración Tributaria.- ………………....17

1.3. Aspectos básicos de la prescripción.- ……………………………………....21

\section{CAPÍTULO II: LA PRESCRIPCIÓN COMO LÍMITE A LA FACULTAD DE} FISCALIZACIÓN Y DETERMINACIÓN..

2.1. ¿Es posible arrastrar los efectos de un período prescrito a uno no prescrito?-.28

2.1.1. ¿Qué extingue la prescripción? ¿La acción y/o el derecho? .28

2.1.2. Solicitud de información de períodos prescritos para determinar obligaciones

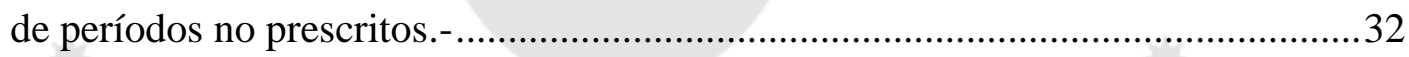

2.1.3. Determinación de la obligación tributaria de períodos prescritos.-

2.1.4. Consecuencias en períodos posteriores de la "determinación" de períodos prescritos.-

2.1.4.1. Primer caso: Modificación de la determinación de un período prescrito para proyectar sus efectos a uno no prescrito en el Impuesto a la Renta.-

2.1.4.2. Segundo caso: modificación de la determinación de un período prescrito para proyectar sus efectos a uno no prescrito en el caso del Impuesto General a las

Ventas.- 
2.1.4.3. Tercer caso: arrastre de pérdidas y saldos a favor..62

2.2. Nuestra propuesta.-

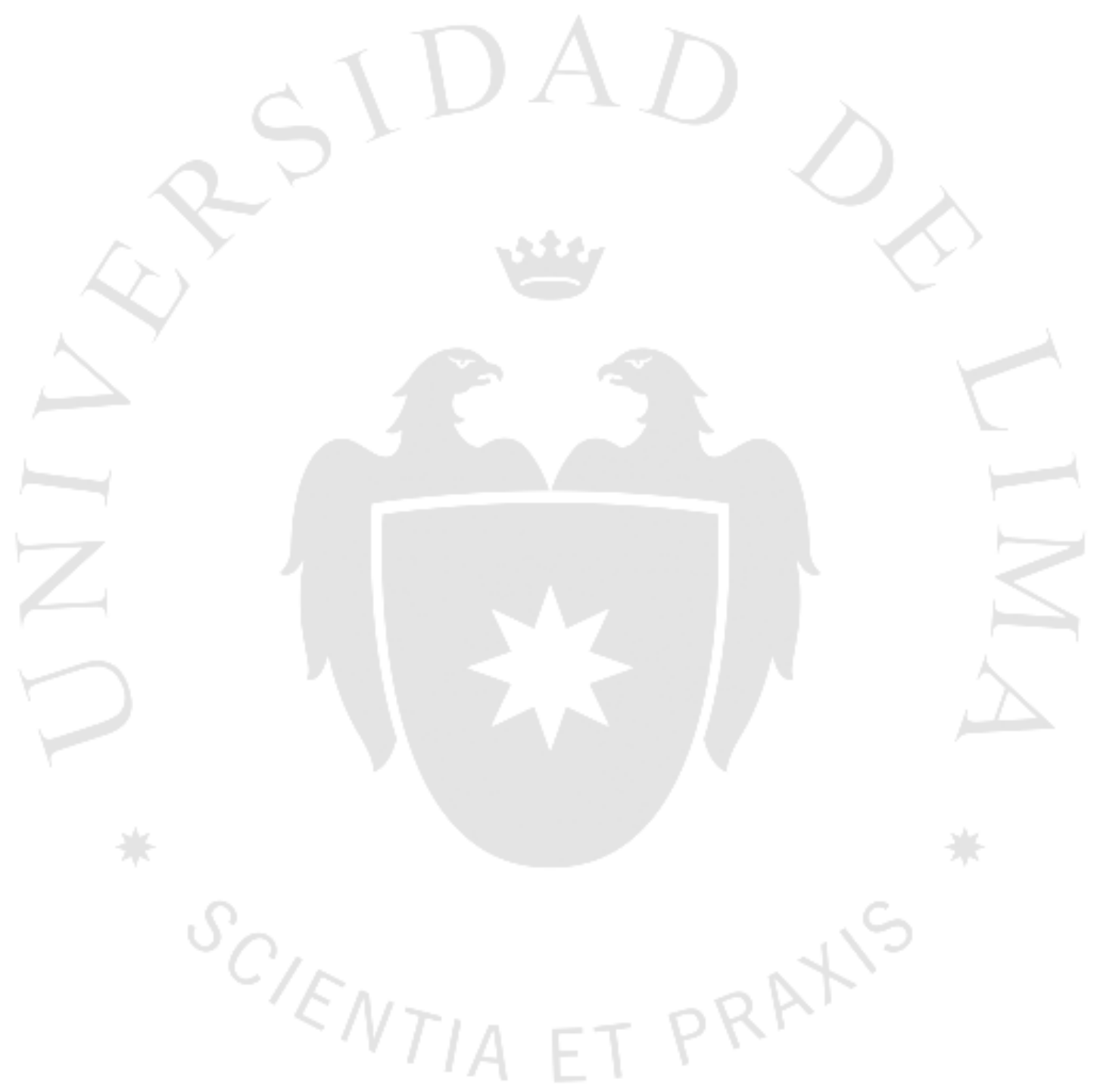




\section{INTRODUCCIÓN}

En el presente trabajo de investigación, analizaremos cómo la prescripción actúa como un límite temporal frente a la facultad de fiscalización y determinación con la que cuenta la Administración Tributaria.

De acuerdo con lo señalado por el Artículo 61 del Texto Único Ordenado del Código Tributario, la determinación de la obligación tributaria efectuada por los deudores tributarios, se encuentra sujeta a fiscalización o verificación por parte de la Administración Tributaria, quien podrá modificarla cuando se constate omisiones o inexactitudes.

Ahora bien, esta facultad no es absoluta y tiene ciertos límites, entre ellos el límite temporal. Así, la acción de la Administración Tributaria para determinar la obligación tributaria prescribe a los cuatro años (sin considerar interrupciones o suspensiones, cuyos supuestos son señalados expresamente en el Código Tributario) por lo que si vencido dicho plazo, no se ha emitido determinación alguna, la declaración jurada efectuada por los contribuyentes debería entenderse como firme y definitiva.

Así, en el primer capítulo de la presente investigación analizaremos los aspectos básicos de las facultades de fiscalización y determinación con las que cuenta la Administración Tributaria y señalaremos qué principios y derechos de los contribuyentes se encuentran involucrados en el ejercicio de tales facultades y determinar los efectos de la prescripción como un límite temporal a las mismas.

No obstante, existen criterios jurisprudenciales que permitirían a la Administración Tributaria revisar hechos y situaciones ocurridas en períodos prescritos para proyectar sus efectos en períodos no prescritos, lo que podría conllevar a un desconocimiento de la seguridad jurídica en la que se basa la prescripción. Así, tanto el Tribunal Fiscal (por ejemplo en las Resoluciones 4000-1-2008, 9508-2-2007, entre otras) y la SUNAT (mediante el Informe $\mathrm{N}^{\circ}$ 162-2006/SUNAT), han señalado que es posible solicitar 
información vinculada con períodos prescritos en la medida que tengan incidencia en períodos no prescritos.

Así mismo, existen otras resoluciones (como las Resoluciones del Tribunal Fiscal $\mathrm{N}^{\circ}$ 17618-1-2012, 100-5-2004 o 13365-3-2013) en las que el Tribunal avala que SUNAT "determine" un período prescrito (sin la emisión de una resolución de determinación) para proyectar los efectos de éste en períodos no prescritos, lo que también podría significar una vulneración a los efectos que produce la prescripción y al principio de seguridad jurídica en el que se basa.

Considerando lo anterior, en el segundo capítulo de la presente investigación analizaremos, en primer lugar, cuáles son los efectos de la prescripción y si una vez transcurrido el plazo prescriptorio se extingue la acción y/o el derecho o si, a pesar de ello, es posible que la Administración Tributaria efectúe una nueva determinación de la obligación tributaria declarada por los contribuyentes.

Es en este contexto que se revisarán las diversas resoluciones emitidas por el Tribunal Fiscal peruano así como jurisprudencia de otros países en los que existen pronunciamientos sobre este tema y donde apreciaremos que no existe un criterio uniforme sobre el límite temporal de la facultad de fiscalización y determinación. Así mismo, como citaremos jurisprudencia extranjera, analizaremos las normas legales que sustentaron estas resoluciones y así determinar cuáles son las similitudes y diferencias con la legislación peruana.

Además, analizaremos los comentarios de la doctrina especializada ante los pronunciamientos del Tribunal Fiscal y revisaremos las posibles vulneraciones o afectaciones a los derechos de los contribuyentes en las que incurriría la Administración Tributaria al solicitar información de períodos prescritos (a los contribuyentes y a terceros) y al determinar la obligación tributaria de estos períodos para proyectar los efectos en ejercicios no prescritos.

En este punto analizaremos tres posibles situaciones: (i) la determinación de un ejercicio prescrito para proyectar sus efectos en un ejercicio posterior no prescrito en el 
caso del Impuesto a la Renta; (ii) la determinación de un ejercicio prescrito para proyectar sus efectos en un ejercicio posterior no prescrito en el caso del Impuesto General a las Ventas; y, (iii) el arrastre de saldos o pérdidas de períodos no prescritos para determinar un nuevo saldo en un período no prescrito.

En el último de estos escenarios planteados analizaremos cuáles son los componentes de la obligación tributaria pues resulta relevante determinar si ésta comprende, además del impuesto determinado, a los saldos a favor, pérdidas tributarias u otros créditos y así conocer hasta dónde llega el alcance de la prescripción y qué elementos se encuentran protegidos por ella.

Finalmente, en función de los distintos aspectos revisados en la investigación, efectuaremos algunas recomendaciones que permitirían, en nuestra opinión, asegurar que se cumplan con los distintos principios y derechos de los contribuyentes reconocidos por la Constitución, vinculados con la prescripción, y que deben ser considerados por la Administración Tributaria al ejercer sus facultades de fiscalización y determinación. 


\section{CAPÍTULO I: ASPECTOS BÁSICOS DE LA FACULTAD DE FISCALIZACIÓN Y DE LA PRESCRIPCIÓN}

Dentro de las facultades con la que cuenta la Administración Tributaria, encontramos la de fiscalización y determinación de la obligación tributaria. Como veremos, si bien esta facultad se sustenta en la potestad tributaria otorgada por la Constitución y por las leyes de la materia, debe tener algunos límites. Entre ellos, analizaremos brevemente el límite vinculado con los derechos fundamentales de los ciudadanos y el cumplimiento de los principios que regulan los actos administrativos.

Así mismo, se revisarán los aspectos básicos de la prescripción así como su vinculación con la seguridad jurídica. Ello, debido a que consideramos que otro de los límites a la facultad de fiscalización y determinación es el aspecto temporal. En base a este límite, la Administración Tributaria puede ejercer la mencionada facultad únicamente dentro del plazo prescriptorio.

\subsection{La facultad de fiscalización de la Administración Tributaria.-}

De acuerdo con lo señalado por el primer párrafo del Artículo 61 del Texto Único Ordenado del Código Tributario (aprobado mediante Decreto Supremo No 133-2013-EF (en adelante, Código Tributario):

La determinación de la obligación tributaria efectuada por el deudor tributario está sujeta a fiscalización o verificación por la Administración Tributaria, la que podrá modificarla cuando constate la omisión o inexactitud en la información proporcionada, emitiendo la Resolución de Determinación, Orden de Pago o Resolución de Multa.

Si bien el Código Tributario otorga la facultad de determinación y fiscalización a la Administración Tributaria, es importante señalar que estas facultades derivan del poder otorgado al Estado en el sentido que debe verificar que los contribuyentes cumplan con 
todas sus obligaciones tributarias; el no hacerlo, implicaría que exista un gran nivel de incumplimiento, pues la recaudación y el cumplimiento serían efectivos para aquéllos que no pueden dejar de cumplir (por ejemplo las retenciones por concepto de cuarta categoría) o por aquéllos que tienen conciencia tributaria ${ }^{1}$.

Existen estudios efectuados por la propia Administración Tributaria ${ }^{2}$ en los que se han analizado las causas que llevan al incumplimiento de las obligaciones tributarias, entre las que tenemos, el beneficio directo derivado de la omisión del pago del tributo, la inexistencia de un nivel de conciencia tributaria ${ }^{3}$, el nivel de tasa efectiva aplicada, la percepción de legitimidad del gobierno, etcétera.

Conociendo entonces la importancia que tiene el cumplimiento de las obligaciones tributarias, consideramos importante analizar el deber de contribuir que tiene cada ciudadano.

Como bien menciona Durán (2006), el deber de contribuir no se encuentra regulado expresamente en la Constitución vigente aunque con los poderes otorgados a la Administración Tributaria podría hablarse de un reconocimiento implícito del deber de contribuir de los contribuyentes como base de todo el sistema (p. 89). Así, resulta claro que cada ciudadano, tiene la obligación o el deber de contribuir con el Estado ${ }^{4}$.

1 Al respecto, resulta interesante lo que señala el Tribunal Constitucional en la Sentencia que resolvió el expediente $\mathrm{N}^{\circ}$ 6089-2006-PA/TC, la misma que en su considerando 21 , indica que lo ideal sería que todos cumplan con soportar de manera igualitaria las cargas públicas, pero que el escenario se torna ficticio cuando no todos cumplen con sus obligaciones.

2 Nos referimos específicamente al estudio denominado "Estimación del incumplimiento en el Impuesto General a las Ventas durante el año 2008" en el que se desarrolla, a manera de introducción, las causales de incumplimiento de las obligaciones. Si bien el estudio data del año 2008, debemos reconocer que tiene plena vigencia pues en nuestra opinión no ha habido avances significativos en este tema. Ver: http://www.sunat.gob.pe/estadisticasestudios/informes_publicaciones/estimacion_incumpl/estimacion_inc umplimiento_igv 2008.pdf

3 En el estudio citado se indica, respecto de la conciencia tributaria, que "en este aspecto es relevante tener en cuenta cuál es el grado de condena social a la evasión, así como los niveles de educación tributaria brindada a los ciudadanos y la existencia o no de valores de solidaridad en el ámbito de la sociedad". Sobre este tema, sí debemos reconocer que en nuestro país no existe una alta conciencia tributaria, lo que queda demostrado con los altos niveles de informalidad en la economía.

4 Respecto del deber de contribuir como concepto, se recomienda revisar el trabajo elaborado por Álvaro Rodríguez Bereijo en el que se desarrolla este tema desde la óptica de la legislación y la doctrina española. 
Respecto de este último aspecto, tal como analizaremos más adelante, tanto la doctrina como la jurisprudencia del Tribunal Constitucional peruano coinciden que el deber de contribuir de todo ciudadano debe tener como límite la capacidad contributiva, pues en caso de no hacer podría llevar a que quienes tengan menores recursos tengan una mayor carga frente al Estado. Al respecto, también resulta importante mencionar que, como desarrollaremos a continuación, el deber de contribuir se encuentra estrechamente ligado al denominado "principio de solidaridad".

Sobre estos temas, García Novoa (2011a) señala lo siguiente:

Entre los bienes constitucionales reconocidos aparece el deber de contribuir vinculado al deber de solidaridad. Desde esta perspectiva, el deber de contribuir deja de definirse a partir de la limitación que le impone el principio de capacidad contributiva, situándose, por el contrario, frente a este principio. Además, el deber de solidaridad se convierte en un factor de fundamentación de las acciones recaudatorias y de la lucha contra la elusión y evasión en general. (p. 60)

$\mathrm{Al}$ respecto, el Tribunal Constitucional se ha pronunciado en múltiple jurisprudencia sobre la relación que existe entre el deber de contribuir, la capacidad contributiva y el principio de solidaridad. A manera de ejemplo, citaremos lo que señaló el mencionado Tribunal al resolver el Expediente $\mathrm{N}^{\circ}$ 6089-2006-PA/TC:

(...) la solidaridad permite entonces admitir una mayor flexibilidad y adaptación a la figura impositiva a las necesidades sociales, en el entendido de que nuestro Estado Constitucional no actúa ajeno a la sociedad, sino que la incorpora, la envuelve y la concientiza en el cumplimiento de los deberes.

En este tipo de Estado el ciudadano ya no tiene exclusivamente el deber de pagar tributos, concebido según el concepto de libertades negativas propio del Estado Liberal, sino que asume deberes de colaboración con la Administración, los cuales se convertirán en verdaderas obligaciones jurídicas. En otras palabras, la transformación de los fines del

Ver: Rodríguez Bereijo, Álvaro (octubre-noviembre de 2008). "El Deber de Contribuir como deber constitucional". Revista Análisis Tributario. $\mathrm{N}^{\circ} 248$ (Primera parte) y $\mathrm{N}^{\circ} 249$ (Segunda parte). Lima: AELE. 
Estado determinará que se pase de un deber de contribuir, basado fundamentalmente en la capacidad contributiva, a un deber de contribuir basado en el principio de solidaridad.

Como podemos observar, en función del deber de contribuir, el principio de solidaridad y el principio de capacidad contributiva, la Administración Tributaria se encuentra facultada para determinar y fiscalizar las obligaciones tributarias de los contribuyentes y su debido cumplimiento. No obstante, es importante precisar que esta facultad otorgada a la Administración Tributaria no es de carácter absoluto.

Como se sabe, existen derechos constitucionales que regulan y limitan en cierto modo esta facultad, impidiendo así que ésta se realice de manera irrestricta. Así, en la Constitución Política del Perú vigente encontramos un primer límite a esta facultad al indicarse que la potestad tributaria debe respetar los derechos fundamentales de la persona, tal como lo establece el Artículo 74 de la Carta Magna 5 .

Si bien doctrinariamente, la gran mayoría de autores señala que este artículo es el que reconoce los derechos fundamentales de los ciudadanos frente a la potestad tributaria del Estado, Danós Ordoñez (1994) tiene una teoría particular al respecto que es importante señalar:

Es novedosa la remisión expresa que el Artículo 74 de la nueva Constitución efectúa a los “derechos fundamentales de la persona" como límites para el ejercicio del poder tributario, aunque en verdad no era indispensable porque se entiende que la eficacia de los derechos constitucionales se proyecta sobre todo el ordenamiento jurídico sin que sea necesaria una norma que remarque la efectividad para la materia tributaria. (p. 140) (el subrayado es nuestro).

No obstante lo indicado anteriormente, en el Perú actualmente pareciera que existe una preferencia por las facultades del Estado frente a los derechos de los contribuyentes; al respecto, compartimos la posición de Gamba (2010a) en este sentido:

5 El segundo párrafo del Artículo 74 de la Constitución Política del Perú señala:

Los Gobiernos Regionales y los Gobiernos Locales pueden crear, modificar y suprimir contribuciones y tasas, o exonerar de éstas, dentro de su jurisdicción, y con los límites que señala la ley. El Estado, al ejercer la potestad tributaria, debe respetar los principios de reserva de la ley, y los de igualdad y respeto de los derechos fundamentales de la persona. Ningún tributo puede tener carácter confiscatorio. 
(...) debemos recordar que en el cuidadoso esquema de valores constitucionales-tributarios, no solo existe un valor susceptible de protección -como el deber de tributar-, como al parecer algunos insisten en sostener, sino -y esto es lo más importante- también existen determinados derechos y garantías constitucionales irrenunciables de los ciudadanos$\underline{\text { contribuyentes, que -pese a encontrarse también reconocidos por el texto constitucional- no }}$ están teniendo la debida atención que merecen. (p. 372) (el subrayado es nuestro).

En este escenario resulta claro que el poder otorgado a la Administración Tributaria para el ejercicio de su facultad de fiscalización y determinación, podría conllevar a la vulneración de una serie de derechos fundamentales de los contribuyentes ${ }^{6}$. Sobre esta posible colisión entre la facultad de la Administración y los derechos fundamentales de los contribuyentes ahondaremos más adelante.

Ello, no conlleva de modo alguno, a desconocer el carácter discrecional con el que se ejerce esta facultad, pero dicho carácter tampoco debe traducirse en una facultad que no conozca límites, más aún, si se trata de principios reconocidos constitucionalmente.

6 Cesar Gamba señala también en otro artículo que Resulta que las normas tributarias vienen atendiendo exclusivamente al interés fiscal, inclinando la balanza hacia los poderes que la Administración en desmedro de las garantías y derechos fundamentales de los ciudadanos-contribuyentes (también valores y bienes de carácter constitucional. Hay, pues, un descuido indiscutible de los derechos fundamentales de los ciudadanos-contribuyentes; $\mathrm{y}$, por lo tanto, una desprotección evidente de estos últimos.

Ver: Gamba Valega, César (2010b). "Los efectos del Texto Constitucional en el Ordenamiento Tributario". Revista del Instituto Peruano de Derecho Tributario. № 50. Lima. p.89.

En el mismo sentido se pronuncia Percy Bardales Castro, al señalar que Ciertamente, los deudores tributarios entienden que, aun cuando la imposición tributaria es una relación de derecho que debe estar sujeta a reglas, el ejercicio de las potestades de fiscalización y, consecuente, determinación de las obligaciones tributarias por parte de la autoridad tributaria debe respetar y hacer prevalecer ciertos derechos, valores y principios de reconocido orden constitucional. Así, producto de dicha constatación, por ejemplo, se exige la vigencia material de los límites constitucionales y legales previstos para la regulación y ejercicio de dichas potestades, ya sea en lo relativo a la naturaleza del tributo, a la capacidad contributiva, a la seguridad jurídica, la predictibilidad, la certeza, la definitividad, la preclusividad de la liquidación tributaria, entre otros aspectos. Dicha exigencia, empero, a entender de los deudores tributarios, no se estaría presentando ni dando fuerza normativa - en la realidad- en todos los casos.

Ver: Bardales Castro, Percy (2010). Breves notas sobre los límites constitucionales a la aplicación de presunciones legales en el procedimiento de determinación de la obligación tributaria. En: Lara Márquez, Jaime (director). Libro Homenaje a Luis Hernández Berenguel. Lima: Instituto Peruano de Derecho Tributario. pp. 589-590. 
Respecto de la discrecionalidad, debemos indicar que de acuerdo con lo señalado por el Artículo 62 del Código Tributario, la facultad de fiscalización de la Administración Tributaria, se ejerce de manera discrecional, conforme lo establece el último párrafo de la Norma IV del Título Preliminar ${ }^{7}$.

Al respecto, la doctrina (por ejemplo, Terrones, Gamba y Villegas, cuyos posiciones analizaremos a continuación) tiene un criterio uniforme en el sentido que esta discrecionalidad implica que la Administración Tributaria puede seleccionar a los contribuyentes que fiscalizará, puede determinar los tributos y períodos que serán materia de revisión, definir cuáles serán los puntos que se revisarán y analizarán y de qué manera se realizará la fiscalización. No obstante, es importante destacar que la discrecionalidad no debe entenderse de manera absoluta sino que debe ser utilizada dentro de los marcos legales establecidos y ser ejercida con la debida motivación.

En un interesante trabajo al respecto, Terrones López (2010) señala que todos los actos que realice la Administración Tributaria deben der motivados, incluso aquéllos que sean realizados en el ejercicio de su facultad discrecional, posición que compartimos y que nos lleva a preguntarnos si al ejercer su facultad de fiscalización y determinación, la Administración Tributaria cumple con la motivación. (p. 209)

Sabemos que la facultad de fiscalización y determinación con la que cuenta la Administración Tributaria, es ejercida de manera discrecional respecto de los contribuyentes que son fiscalizados, los tributos que son materia de revisión, etcétera. Sin embargo, si revisamos una carta mediante la cual se comunica el inicio de una fiscalización, la Administración Tributaria no incluye los motivos por los cuales se inicia la revisión; únicamente se señala que ésta se realiza en virtud de las facultades que le otorga el Código Tributario.

7 El último párrafo de la Norma IV del Título Preliminar del Código Tributario señala: “En los casos en que la Administración Tributaria se encuentre facultada para actuar discrecionalmente optará por la decisión administrativa que considere más conveniente para el interés público, dentro del marco que establece la ley". 
No conocemos que existan documentos -al menos no conocemos que hayan sido publicados- en los que se establezca un procedimiento para la selección de los contribuyentes que serán materia de revisión y, en caso existir -a nivel interno-, si se siguen criterios objetivos que busquen reducir la informalidad y el incumplimiento de las obligaciones tributarias ${ }^{8}$.

Continuando con la discrecionalidad en los procedimientos de fiscalización y determinación, Gamba (1999) señala que la facultad otorgada en el Artículo 62 del Código Tributario es un claro ejemplo de la potestad discrecional de la Administración Tributaria:

Efectivamente, piénsese en la amplia libertad de la que goza la Administración para elegir o determinar a los sujetos que serán objeto de una fiscalización. Pero, si bien este margen de libertad parece ser bastante extenso, las decisiones administrativas que se adopten sobre el particular también se encuentran sometidas a Derecho; es decir, la elección de los sujetos a fiscalizar debe obedecer a criterios o parámetros de carácter técnico, para no ser arbitrarios. (p. 121, 122) (el subrayado es nuestro).

$\mathrm{Al}$ respecto también se ha pronunciado Villegas Lévano (2011), quien indica que:

(...) 'discrecionalidad' no es la puerta a la arbitrariedad o abuso por parte de la autoridad administrativa, sino que significa la toma (de) decisiones dentro del marco y las limitaciones de la ley. Y aplicando esta precisión a la Administración Tributaria, ésta debe ejercer su facultad fiscalizadora de forma discrecional, como le faculta el Código Tributario, pero no con poder absoluto, omnímodo e ilimitado, sino en un marco de legalidad que garantice validez y legitimidad del acto. (p. 499)

Finalmente, el Tribunal Constitucional ha señalado en la sentencia que resolvió el Expediente $\mathrm{N}^{\circ}$ 4168-2006-PA/TC, lo siguiente:

El artículo 74 de la Constitución, segundo párrafo, establece que al ejercer la potestad tributaria el Estado debe respetar los derechos fundamentales de las personas. De igual modo se ha expuesto en la jurisprudencia de este Colegiado que los "principios constitucionales tributarios son límites al ejercicio de la potestad tributaria, pero también

Cabe precisar, por ejemplo, que los denominados "mega contribuyentes" de la Intendencia de Principales Contribuyentes Nacionales, son fiscalizados continuamente y no necesariamente son un ejemplo de informalidad o incumplimiento de obligaciones. 
son garantías de las personas frente a esa potestad" [STC 0042-2005-AI/TC, fundamento 7]. Así, esta potestad tributaria, en su dimensión fiscalizadora, es regulada en el Texto Único Ordenado del Código Tributario (aprobado mediante Decreto Supremo N. ${ }^{\circ} 135-99-E F$ ), que en su artículo 62 establece las facultades discrecionales concedidas a la Administración Tributaria a fin de que pueda cumplir con su labor recaudatoria. Esta actividad, normada por Ley, otorga gran amplitud de acción a la Administración, precisamente para combatir la evasión tributaria. Sin embargo, y como ya se apreció, este amplio margen de actuación se encuentra limitado. En efecto, mientras mayor sea la discrecionalidad de la Administración mayor debe ser la exigencia de motivación de tal acto, ya que la motivación expuesta permitirá distinguir entre un acto de tipo arbitrario frente a uno discrecional. (El subrayado es nuestro).

Con lo antes expuesto, resulta claro que, como mencionamos anteriormente al desarrollar nuestra posición sobre el tema, los derechos fundamentales de los contribuyentes actúan como un límite a la facultad de fiscalización y determinación que es ejercida por la Administración Tributaria, posición que es avalada por la doctrina y el Tribunal Constitucional.

Así mismo, podemos indicar que esta facultad de fiscalización, vinculada con un procedimiento que sigue la Administración Tributaria para verificar la correcta determinación de la obligación tributaria, debe ceñirse a lo dispuesto por la Ley del Procedimiento Administrativo General (Ley $N^{\circ}$ 27444). En esta Ley, no solo se incluyen los derechos que tienen los contribuyentes, sino también una serie de principios que deben ser respetados en todo procedimiento, tales como el de razonabilidad, idoneidad, entre otros.

Como puede apreciarse, la Administración Tributaria cuenta con el poder otorgado por la potestad tributaria para el ejercicio de la facultad de fiscalización y determinación de la obligación tributaria, pero por otro lado, se tiene a los derechos fundamentales de los contribuyentes y el cumplimiento de los diversos principios que son reconocidos por la Constitución y reafirmados y desarrollados en la Ley del Procedimiento Administrativo General como un límite. 
En este escenario, podría existir una colisión entre la potestad tributaria de la Administración Tributaria, ejercida mediante la facultad de fiscalización y determinación y, por otro lado, los derechos fundamentales de los contribuyentes.

Como ya ha sido desarrollado en múltiples resoluciones del Tribunal Constitucional en este caso procedería efectuar un test de proporcionalidad ${ }^{9}$, en el que debería analizarse qué principio, valor o derecho prevalece sobre el otro ${ }^{10}$.

En nuestra opinión, y como se ha desarrollado anteriormente, las facultades ejercidas por la Administración Tributaria no pueden ser, de ninguna manera, de carácter absoluto e irrestricto ni amparar su actuar en los poderes conferidos por la Constitución y la discrecionalidad otorgada por el Código Tributario.

Esta posición también es sostenida por Villegas Lévano (2011), quien señala que “(...) las facultades discrecionales no se ejercen al libre albedrío de los funcionarios de la Administración Pública, ni tampoco son puerta abierta para la arbitrariedad, ni a la voracidad recaudadora del ente fiscal." (p. 504)

Así, cada una de sus acciones debe respetar los derechos fundamentales de los ciudadanos. Con ello, podríamos definir que las facultades de la Administración Tributaria corresponden a un poder o valor atenuado (no absoluto ni ilimitado) que de ningún modo supera los derechos fundamentales de los ciudadanos.

Como segundo aspecto encontramos el límite temporal. Ello, debido a que los contribuyentes deben conocer el espacio temporal que en el que la facultad de la Administración Tributaria puede ser ejercida, en cumplimiento de lo señalado en las

9 Sobre este tema recomendamos revisar el trabajo de Marcial Rubio Correo en el que se analizan diversas resoluciones del Tribunal Constitucional. Ver: Rubio Correa, Marcial (2011). El Test de Proporcionalidad en la Jurisprudencia del Tribunal Constitucional Peruano. Lima: Fondo Editorial de la Pontificia Universidad Católica del Perú.

10 Para una visión distinta sobre la posible colisión de derechos recomendamos revisar la posición que adopta Luis Castillo Córdova, quien indica que "los llamados conflictos entre derechos fundamentales solo puede ser aparentes, no pueden existir realmente. Los verdaderos conflictos solo pueden verificarse en el ámbito de las pretensiones o de los intereses que en un litigio concreto presenten las partes. En este nivel, sí puede afirmarse que una pretensión ha prevalecido sobre la otra". Ver: Castillo Córdova, Luis Fernando (2005). “¿Existen los llamados conflictos entre derechos fundamentales?”. Cuestiones Constitucionales 12. México: Universidad Nacional Autónoma de México. pp. 99-129. 
normas, no permitiendo que la revisión de los actos de los contribuyentes (en este caso, específicamente la determinación de la obligación tributaria) pueda efectuarse de manera indefinida en el tiempo. Si bien este aspecto será desarrollado en el acápite 3 del presente capítulo y además será analizado a detalle en el capítulo 2 del presente trabajo de investigación, consideramos importante destacar lo señalado por Pantigoso (2012), quien indica:

(...) el ejercicio de la fiscalización tiene un límite temporal correspondiente al término de la prescripción señalada en el Código y, por ello, la Administración no podrá, en teoría, revisar períodos prescritos.

Sin embargo, se ha determinado que es obligación del administrado proporcionar a la Administración la información que le sea requerida respecto de los períodos tributarios que se fiscalicen, debiendo por ello entregar al Fisco toda aquella documentación relevante para la determinación de obligaciones tributarias no prescritas, incluso documentación de períodos prescritos que tuvieran incidencia en la determinación de los períodos analizados.

Esto último genera muchas veces altos costos de almacenamiento de documentación para el contribuyente, $\underline{\text { lo cual no debería suceder en un sistema que respete }}$

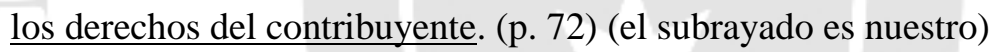

Como prólogo de este acápite, podemos precisar que el Tribunal Fiscal, en la Resolución $\mathrm{N}^{\circ}$ 05288-2-2202, ha definido la fiscalización de la siguiente manera:

Debe tenerse en cuenta que la fiscalización no consiste en un solo acto, sino en un conjunto de actos. En el caso de la Superintendencia Nacional de Administración Tributaria la fiscalización normalmente, se inicia con una carta y un requerimiento exigiendo la documentación contable necesaria para realizarla, a través de la inspección o inspecciones sobre todo aquel documento que evidencie los hechos gravados. Se recoge esta información, se analiza en papeles de trabado que se agregarán al expediente y se da a conocer los resultados de la fiscalización en una actuación en la que participa el mismo sujeto fiscalizado. Además en el curso de ella pueden existir también actos del mismo deudor tributario, tales como la presentación de informes o declaraciones rectificatorias o la verificación de pericias, inspecciones en otros lugares, tomas de inventario, etc. 
Cabe señalar que el Artículo 75 del Código Tributario, establece que concluido el proceso de fiscalización o verificación, la Administración Tributaria emitirá la correspondiente resolución de determinación, resolución de multa u orden de pago, si fuera el caso.

De lo expuesto, se tiene que la fiscalización es un procedimiento, cuya finalidad es la de determinación de la obligación tributaria, la que se traduce en el valor respectivo, de determinación de crédito o deuda tributaria.

Consideremos que, tal como señala esta última resolución, la finalidad de la fiscalización es determinar la obligación tributaria, determinando deuda tributaria o la existencia de un crédito. Esto es de vital importancia para los casos que analizaremos en el siguiente capítulo de la presente investigación.

Ahora bien, como se ha desarrollado anteriormente, la facultad de fiscalización con la que cuenta la Administración Tributaria requiere, antes de ser ejercida, que exista una determinación de la obligación tributaria, a la que nos referiremos en el siguiente acápite.

\subsection{La determinación de la obligación tributaria.-}

El Artículo 88 del Código Tributario define a la declaración tributaria como la manifestación de hechos comunicados a la Administración Tributaria y que puede constituir la base para la determinación de la obligación tributaria ${ }^{11}$. En nuestra opinión, no se refiere a que la declaración tributaria siempre es base para la determinación de la obligación en la medida que existe la posibilidad que la Administración la determine en ausencia de una declaración por parte del contribuyente (por ejemplo, algún omiso a la declaración). Así, este artículo, solo sería de aplicación en los casos de autodeterminación tributaria.

\footnotetext{
11 El primer párrafo del Artículo 88 del Código Tributario señala:

La declaración tributaria es la manifestación de hechos comunicados a la Administración Tributaria en forma y lugar establecidos por Ley, Reglamento, Resolución de Superintendencia o norma de rango similar, la cual podrá constituir la base para la determinación de la obligación tributaria.
} 
El Tribunal Fiscal también se ha pronunciado al respecto; así, mediante Acuerdo de Sala Plena $\mathrm{N}^{\circ} 36-2008^{12}$, se ha establecido que en el caso de tributos autoliquidados por el deudor tributario, la determinación de la obligación tributaria se inicia por su declaración, la que al encontrarse sujeta a verificación o fiscalización por la Administración Tributaria, puede ser modificada emitiéndose una resolución de determinación mediante la cual se da a conocer los resultados de la verificación o fiscalización efectuada.

En otro Acuerdo de Sala Plena, el Tribunal Fiscal, citando al profesor García Novoa (2000) señala que la liquidación tributaria (entendiéndose ésta como la determinación de la obligación tributaria), es:

Un instrumento de generación de certidumbre, en tanto supone 'la declaración de voluntad de la Administración sobre el an y el quantum de la obligación tributaria material', haciéndola inmodificable en el transcurso del procedimiento de gestión y considerando finalizada la función pública en el caso concreto. (p. 1531)

Así mismo, a nivel doctrinario, podemos citar la definición de determinación de la obligación tributaria que realiza Giuliani Fonrouge (2004):

La determinación de la obligación tributaria consiste en el acto o conjunto de actos emanados de la Administración, de los particulares o de ambos coordinadamente, destinados a establecer en cada caso particular la configuración del presupuesto de hecho, la medida de lo imponible y el alcance de la obligación (...). (p. 529)

También podemos mencionar la definición brindada por García Belsunce (2003), quien manifiesta:

(...) para que el Impuesto sea percibido por la Administración, deberá cuantificarse a fin de establecer el valor que el responsable del tributo debe ingresar.

Ese acto de cuantificación es realizado, conforme a la legislación de muchos países, por el propio obligado sin la intervención de la autoridad administrativa, pero en otros supuestos, la cuantificación la efectúa la Administración. (p. 223).

12 Ver página 2 del informe final que forma parte de este acuerdo, de fecha 17 de diciembre de 2008. 
En el Perú, Luis Hernández Berenguel, citando una ponencia de Talledo Mazú (1990), define a la determinación de la siguiente manera:

Por determinación entendemos, entonces, el acto del deudor tributario o del órgano administrador del tributo, o de ambos, en virtud del cual se verifica si se ha producido o no el hecho imponible y quién es el deudor tributario, así como cuál es la base imponible y la cuantía del tributo. (p. 83).

También resulta interesante, la definición brindada por Villegas (2002):

La determinación tributaria es el acto o conjunto de actos dirigidos a precisar en cada caso si existe una deuda tributaria, quién es el obligado a pagar el tributo al fisco (sujeto pasivo) y cuál es el importe de la deuda. (p. 346)

Así mismo, respecto de qué debe entenderse por obligación tributaria (que es lo que se determina finalmente), el Código Tributario en su Artículo 1 señala que "la obligación tributaria, que es de derecho público, es el vínculo entre el acreedor y el deudor tributario, establecido por ley, que tiene por objeto el cumplimiento de la prestación tributaria, siendo exigible coactivamente.

A nivel doctrinario, Talledo Mazú (1987) señala que "por obligación tributaria se entiende el deber o cargo del contribuyente o responsable de pagar un tributo a un determinado acreedor tributario".

Según lo establecido por los Artículos 59 y 60 del Código Tributario, la determinación de la obligación tributaria puede realizarse por el propio deudor tributario (en la denominada autodeterminación) y por la Administración Tributaria, como conclusión al proceso de fiscalización.

Además, debemos indicar que la determinación de la obligación tributaria, no puede ser entendida únicamente en el supuesto que exista un importe por regularizar a favor de la Administración Tributaria; consideramos que dentro del concepto de obligación tributaria y su determinación también deben encontrarse los créditos a favor del contribuyente. 
Sobre el particular se ha pronunciado el Tribunal Fiscal mediante la Resolución $N^{\circ}$ 3859-32003, en la cual señala que:

(...) de acuerdo con lo establecido por el Artículo 59 del Código Tributario, la Administración Tributaria tiene entre otras facultades, la de determinar la deuda tributaria, la cual una vez ejercida y luego de concluido el proceso de fiscalización o verificación, da lugar a la emisión de los valores, entre ellos, las resoluciones de determinación mediante las cuales se establece la existencia de una deuda como del crédito tributario.

Como puede observarse, como resultado de la determinación de la obligación tributaria, se puede establecer la existencia de una deuda tributaria o de un crédito tributario a favor del contribuyente.

Efectuar una interpretación restrictiva, entendiendo que la obligación tributaria se encuentra referida únicamente a los supuestos en los que existe una deuda tributaria a favor del fisco, resultaría errónea en la medida que los créditos tributarios o saldos a favor de los contribuyentes también forman parte de la obligación tributaria. Así, de considerarse esta posición restrictiva solo se entendería por obligación tributaria a aquélla que resulte de aplicar la tasa del impuesto sobre la renta neta imponible, desconociendo considerar los saldos, créditos o pagos a cuenta efectuados por el contribuyente, que para efectos prácticos y, siguiendo lo dispuesto por el Artículo 88 de la Ley del Impuesto a la Renta, forman parte de la determinación de la obligación tributaria y así determinar si existe un saldo a favor o una deuda tributaria.

El referido Artículo 88 de la Ley del Impuesto a la Renta, en su inciso c), indica expresamente que:

Los contribuyentes obligados o no a presentar las declaraciones a que se refiere el Artículo 79, deducirán de su impuesto los conceptos siguientes:

(...)

Los saldos a favor del contribuyente, reconocidos por la SUNAT o establecidos por el propio contribuyente en sus declaraciones juradas anteriores como consecuencia de los créditos autorizados en este artículo, siempre que dichas declaraciones no hayan sido 
impugnadas. La existencia y aplicación de estos últimos saldos quedan sujetos a verificación por parte de la mencionada Superintendencia.

Así, resulta claro que los saldos a favor forman parte de la determinación del Impuesto a la Renta y por consiguiente deberían ser alcanzados también por los efectos de la prescripción.

\subsubsection{La autodeterminación.-}

Como ya hemos señalado anteriormente, el Código Tributario estipula que la determinación puede realizarse por el propio deudor tributario o por la Administración Tributaria. En el presente acápite revisaremos la primera de ellas, la autodeterminación.

De la lectura del Artículo 59 del Código Tributario, se desprende que la denominada autodeterminación formulada por el deudor tributario, constituye una forma de determinación que se encontrará sujeta a una fiscalización y una nueva determinación por parte de la Administración Tributaria dentro del plazo de prescripción. Por ello, la autodeterminación podría incluso denominarse como una determinación provisional pues si bien es un acto firme, solo será definitiva cuando no exista la posibilidad de revisión por parte de la Administración Tributaria.

La autoliquidación de los tributos, que es el modelo que adopta nuestro Código Tributario para las obligaciones más importantes (léase Impuesto a la Renta e Impuesto General a las Ventas), tiene su fundamento en el deber de colaboración que todo ciudadano tiene frente a la Administración Tributaria ${ }^{13}$.

Sin embargo, si bien la autodeterminación puede tener el sustento en el deber de colaboración, también es cierto que mediante este sistema, existe un traslado de

13 Resulta interesante el análisis efectuado por César García Novoa quien señala que "la importancia en los modernos sistemas tributarios de los impuestos de incidencia masiva hace de las obligaciones de colaboración de los obligados tributarios un elemento cardinal de la gestión tributaria". En: García Novoa, César (2011b). Iniciación, interrupción y cómputo del plazo de prescripción de los tributos. Madrid: Editorial Marcial Pons. p. 29. 
responsabilidad hacia el administrado por parte del Estado. En esta línea se pronuncia Vargas León (junio 1992):

(...) la llamada autodeterminación de la obligación tributaria se encuadra dentro de una creciente tendencia actual en virtud de la cual el Estado, en parte por su organización defectuosa y en parte por simplificar y reducir su estructura, externaliza en los administrados algunos de sus costos, haciéndolos responsables de diversas funciones que potencialmente le corresponde realizar a él. (p. 98)

Ahora bien, debemos indicar que si bien existe la posibilidad de revisión por parte de la Administración Tributaria, la autodeterminación contiene un nivel de certeza al darle el carácter de declaración jurada. Así ha sido entendido por el Tribunal Fiscal, que señaló lo siguiente en la Resolución N 12988-1-2009:

(...) cuando se presenta una declaración relacionada con la determinación del tributo, no se hace un mero aporte mecánico de datos sino que previamente debe realizare una valoración de los hechos y de las normas aplicables, siendo que lo declarado y determinado debe tener un respaldo en la realidad, a través de documentos, libros contables y otros medios probatorios pertinentes admitidos legalmente.

Esta labor del deudor tributario, que coadyuva para la determinación final de la obligación tributaria a su cargo, es de tal importancia que el Código Tributario presume que dicha declaración es jurada, lo cual es consecuente con la valoración previa que debe realizarse (...). (el resaltado es nuestro).

Como puede apreciarse, la determinación efectuada por el contribuyente debe ser cierta, en la medida que se trata de una declaración jurada del contribuyente. No obstante, ese nivel de certeza no resulta absoluto pues lo determinado por el contribuyente puede encontrarse sujeto a una posterior verificación por parte de la Administración Tributaria.

Si bien el escenario ideal en esta revisión es que no exista observación alguna, lo que significaría una correcta determinación efectuada por el contribuyente. Para ello, sería importante que los mecanismos de declaración sean sencillos y así tener un menor número de litigios o discrepancias entre los contribuyentes y la Administración Tributaria. 
Sobre esto último resulta interesante la conclusión a la que llega Luqui (1989) sobre las autodeterminaciones:

Ahora bien, si la preparación de aquellas declaraciones fuera sencilla, por lo menos el contribuyente podría cumplir su obligación sin mayor esfuerzo, pero lo cierto es que en algunas oportunidades es menester tener conocimientos muy completos, no solamente de contabilidad sino de derecho, y entonces es cuando sobrevienen todos los inconvenientes y protestas que son frecuentes. (p. 289)

Es así que si bien la autodeterminación es el mecanismo más utilizado en nuestro país y que es el pilar para el pago del Impuesto a la Renta de tercera categoría e Impuesto General a las Ventas, también es cierto que actualmente sigue siendo un proceso complejo que podría llevar a error a los contribuyentes y que genera las múltiples discrepancias con la Administración Tributaria. Con la implementación de libros electrónicos y facturas electrónicas se espera que las autodeterminaciones sean más sencillas y permitan el correcto cumplimiento de las obligaciones.

\subsubsection{Determinación por parte de la Administración Tributaria.-}

Recordemos que el Artículo 75 del Código Tributario señala que concluido el procedimiento de fiscalización, la Administración emitirá la resolución correspondiente ${ }^{14}$; esto resulta importante porque en el presente trabajo de investigación, se analizará cómo la prescripción constituye un límite temporal para la facultad de fiscalización en el entendido que ésta concluye justamente con una resolución de determinación. No existe la posibilidad que se dé por concluido un procedimiento de fiscalización sin que se emita esta resolución (aunque sea por importe cero) pues de acuerdo con el Artículo 76 del Código Tributario, la resolución de determinación es el acto por el cual la Administración Tributaria pone en conocimiento del deudor tributario el resultado de su labor destinada a controlar el

14 El primer párrafo del Artículo 75 del Código Tributario señala: "Concluido el proceso de fiscalización o verificación, la Administración Tributaria emitirá la correspondiente Resolución de Determinación, Resolución de Multa u Orden de Pago, si fuera el caso”. 
cumplimiento de las obligaciones tributarias (léase facultad de fiscalización) y establece la existencia del crédito o de la deuda tributaria.

Ahora bien, dentro las características que debe contener esta determinación efectuada por la Administración Tributaria, es que ésta debe ser única, integral ${ }^{15}$ y definitiva. Esta tesis fue planteada por Hernández Berenguel (1998), quien señala lo siguiente:

En efecto, si la Administración posee todas las facultades necesarias para realizar una fiscalización o verificación profundas del cumplimiento de las obligaciones tributarias por el deudor tributario, no existe razón para que la determinación sea parcial -lo que implicaría que con posterioridad podrían existir otras determinaciones parciales respecto del mismo tributo y periodo- ni, por lo tanto, para que respecto del mismo tributo y periodo pueda existir más de una determinación -salvo las excepciones debidamente justificadas y expresa y taxativamente previstas en la ley- porque la única que debe practicarse tiene que ser integral y, por ende definitiva. (p. 12) (el resaltado es nuestro).

Si bien se admiten ciertas excepciones (que son las previstas en el Artículo 108 del Código Tributario), la resolución de determinación debe ser: (i) única, porque la Administración debe fiscalizar una sola vez dentro del término prescriptorio (refiriéndonos al caso de las fiscalizaciones definitivas); (ii) integral, porque debe abarcar todos los aspectos relacionados con el tributo y período materia de fiscalización; y, (iii) definitiva, porque no puede ser modificada y en tanto no sea impugnada por el deudor tributario. (Hernández Berenguel, 2009, p. 19).

Respecto del carácter definitivo, mencionamos anteriormente que en el caso de las autodeterminaciones, éstas tenían un carácter temporal pues se encontraban sujetas a revisión por parte de la Administración Tributaria. Así, en el caso de las determinaciones que se producen luego de concluido el procedimiento de fiscalización, sí podemos afirmar que constituyen una determinación firme y definitiva pues ya no podrá ser materia de una nueva revisión (salvo los supuestos expresamente señalados en el Código Tributario).

15 A excepción de las fiscalizaciones parciales, que no serán materia de análisis en la presente investigación. 
Como ya se ha mencionado, a raíz de la fiscalización efectuada, la Administración Tributaria necesariamente debe emitir una Resolución de Determinación (aunque esté de acuerdo con la determinación de la obligación tributaria efectuada por el contribuyente y emita la resolución por importe cero) porque mediante ésta se agota su acción para determinar la deuda tributaria ${ }^{16}$.

Este criterio es el que ha adoptado el Tribunal Fiscal pues el Acuerdo de Sala Plena $\mathrm{N}^{\circ}$ 2005-25 de fecha 19 de julio de 2005 (que dio lugar a la emisión de la Resolución $\mathrm{N}^{\circ}$ 4638-1-2005, que constituye jurisprudencia de observancia obligatoria) señala:

De lo expuesto se concluye que nuestro sistema tributario reconoce a la Administración la facultad de redeterminar la obligación tributaria del deudor tributario, pudiendo modificar la realizada por éste, ya sea para establecer deuda o saldo a su favor, para lo cual debe emitir y notificar una resolución de determinación por un tributo y período concretos, dentro de un determinado período de tiempo, cual es el de prescripción, determinación que supone en la actualidad y dada la eliminación de las acotaciones parciales, una acción única, integral y definitiva (...), por lo que una vez efectuada ésta y plasmada en una resolución de determinación, culmina la potestad de la Administración para determinar la deuda tributaria del contribuyente $(\ldots)^{p 17}$ (el subrayado es nuestro).

En este mismo sentido y ahondando en la importancia de la emisión de una resolución de determinación para finalizar el procedimiento de fiscalización y determinar la obligación tributaria de manera definitiva, en la mencionada Resolución del Tribunal Fiscal $N^{\circ} 4638$ 1-2005, se fija el siguiente criterio:

La notificación de la resolución de determinación agota la acción de la Administración para determinar la deuda tributaria, interrumpe la prescripción de la acción para su cobro, dando

16 Resulta interesante el criterio establecido en la Resolución del Tribunal Fiscal $N^{\circ}$ 137-5-2000 en la que se exige a la Administración Tributaria que emita una Resolución de Determinación como consecuencia de una fiscalización efectuada por la presentación de una declaración jurada rectificatoria y no una simple carta manifestando su disconformidad.

17 Cabe precisar que al momento de la adopción del acuerdo no se encontraba vigente la regulación de las fiscalizaciones parciales, las mismas que al momento de la elaboración de la presente investigación sí tienen una regulación especial. 
inicio a un nuevo término prescriptorio de la acción para exigir el pago de la deuda acotada en dicho valor (...).

Así, resulta claro que la acción de la Administración para determinar la deuda tributaria concluye con la notificación de la resolución de determinación ${ }^{18}$ y que, en aplicación de lo dispuesto por el Artículo 75 del Código Tributario, esta resolución se emite como consecuencia del término de la físcalización realizada.

A nivel doctrinario, Caller Ferreyros (2005) ha indicado lo siguiente al referirse a la facultad para determinar la obligación tributaria:

(...) es mediante la notificación de la resolución de determinación que la Administración Tributaria agota su acción para determinar la obligación tributaria, y como bien señala Hernández Berenguel, la determinación por la Administración Tributaria es una facultad que legalmente se le atribuye a ella y que ésta debe ejercer dentro de un plazo determinado. Ejercida tal facultad dentro del citado plazo, si como consecuencia de ello se ha establecido una deuda, lo que corresponde única y exclusivamente es exigir su pago u que se inicie el cómputo del plazo prescriptorio establecido para dicho efecto.

Dicho criterio ha sido establecido como precedente de observancia obligatoria por el Tribunal Fiscal en su Resolución No. 4638-1-2005, en la que se señala que La notificación de la resolución de determinación agota la acción de la Administración para determinar la deuda tributaria, interrumpe la prescripción de la acción para su cobro, dando inicio a un nuevo término prescriptorio de la acción para exigir el pago de la deuda acotada en dicho valor, situación reconocida en el último párrafo del texto original del artículo 45 del Texto Único Ordenado del Código Tributario aprobado por Decreto Supremo No. 03599-EF. (p. 40)

Como desarrollaremos en el segundo capítulo de la presente investigación, debemos considerar que la única manera prevista en el Código Tributario para que la Administración Tributaria modifique la determinación efectuada por el contribuyente es mediante la emisión del acto administrativo denominado Resolución de Determinación.

18 Si bien nos referimos a una Resolución de Determinación, es importante señalar que el Tribunal Fiscal, en la Resolución N $\mathrm{N}^{\circ}$ 376-1-2008, señaló que las observaciones que realice la Administración Tributaria a la determinación que realice el contribuyente, pueden formalizarse por cualquier comunicación escrita, siempre y cuando reúna los requisitos de una Resolución de Determinación. 
Así, podemos concluir que no existe acto administrativo alguno, distinto a una Resolución de Determinación, mediante el cual la Administración Tributaria pueda determinar la obligación tributaria y que incluso, en caso no exista observación alguna a lo determinado por el contribuyente, existe la obligación que se emita este acto (con importe cero) mediante el cual concluye de manera formal la facultad de fiscalización y determinación de la Administración.

Además, como veremos a continuación al analizar la institución de la prescripción, esta determinación únicamente puede realizarse en la medida que la mencionada resolución sea emitida dentro del plazo que otorga el Código Tributario para hacerlo pues no puede mantenerse eternamente abierta esta posibilidad, lo cual generaría incertidumbre en los administrados.

\subsection{Aspectos básicos de la prescripción.-}

Respecto de la prescripción, es importante señalar que su definición se encuentra contenida en las normas vinculadas con el Derecho Civil, más no en las normas que regulan el derecho tributario. En ese sentido, desde la perspectiva civil, podría señalarse que la prescripción "es un medio o modo por el cual, en ciertas condiciones, el transcurso del tiempo modifica sustancialmente una relación jurídica” (Vidal Ramirez, 1985, p. 83).

Si bien a nivel doctrinario se indica que la prescripción puede ser adquisitiva o extintiva, para efectos del presente trabajo de investigación únicamente nos centraremos en la última de las mencionadas pues analizaremos la institución de la prescripción como un modo de extinción del derecho que tiene la Administración para fiscalizar y finalmente determinar la obligación tributaria de los contribuyentes.

A nivel tributario, la prescripción se encuentra regulada en el Artículo 43 del Código Tributario, señalándose que la acción de la Administración Tributaria para determinar la obligación tributaria, así como para exigir su pago y aplicar sanciones prescribe a los cuatro años y a los seis años para quienes no hayan presentado la declaración respectiva. 
Así mismo, conforme lo señala el Artículo 47 del Código Tributario, no existe la posibilidad que la prescripción sea declarada de oficio por la Administración Tributaria; siempre debe ser alegada por el contribuyente. Precisa el Artículo 48 del Código Tributario que esta alegación puede efectuarse en cualquier estado del procedimiento administrativo o judicial.

Lo señalado anteriormente es importante porque resulta imprescindible que los contribuyentes cuenten con la seguridad jurídica que su determinación no se verá modificada luego del plazo prescriptorio. Tanto a nivel doctrinario como jurisprudencial, se ha destacado la necesidad de contar con este plazo de prescripción.

Al respecto, Rubio Correa (1987) señala:

(...) el derecho ha considerado necesario establecer plazos dentro de los cuales se debe ejercitar los derechos y otros plazos en los que la inactividad del titular determina su privación o desprotección de aquello que jurídicamente le corresponde, siendo la razón de ello el crear seguridad jurídica en el todo social en referencia a quien es el titular efectivo de los derechos, así como garantizar a quien tiene un deber o una deuda, que no pesará indefinidamente sobre él y sus herederos, la responsabilidad de cumplir. (p. 13, 14).

Por su parte, Vidal Ramírez (1985), indica lo siguiente:

(...) la prescripción, por su naturaleza jurídica, constituye un medio de defensa dirigido a extinguir las pretensiones que se quieran hacer valer en vía de acción o de excepción o, como lo señala el postulado del artículo 1989, extingue la acción pero no el derecho mismo, estamos con el razonamiento de Ennecerus en el sentido que el fundamento de orden público de la prescripción concuerda con el interés particular y, por tanto, es suficiente que se ponga en manos de cada cual un medio de protección y que con el fin de salvaguardar la seguridad jurídica y en orden a proteger las pretensiones ilegítimas, el ordenamiento jurídico tiene que aceptar también que el deudor poco escrupuloso, que sabe exactamente que él todavía, está favorecido por las reglas de la prescripción. (p. 114, 115) (el subrayado es nuestro). 
La importancia de la seguridad jurídica como base y fundamento de la institución de la prescripción como posibilidad de los administrados o contribuyentes de alegarla en cualquier momento del proceso, es destacada por Fernández Junqueira (2001), quien señala que:

El fundamento de la prescripción debe venir, forzosamente, de la justificación a la alteración del principio de justica que deja de aplicarse para ceder, en este caso, ante el principio de la seguridad jurídica. En efecto, por exigencia natural del primero las obligaciones deben de cumplirse y son exigibles en todo caso. Es el segundo de los principios señalados, el de seguridad jurídica, el que predica que el cumplimiento de las obligaciones no pueden encontrarse en situación de pendencia en forma indefinida, el que cobra mayor peso en esta confrontación. (p. 17) (el subrayado es nuestro).

En el mismo sentido se ha pronunciado el Tribunal Fiscal, mediante la Resolución $\mathrm{N}^{\circ} 161$ 1-2008, en la que se señala lo siguiente:

(...) el fundamento de la prescripción está en la necesidad de dar un plazo determinado a las situaciones de incertidumbre, de manera que quien presente una conducta de inacción por el tiempo indicado en la norma perderá la oportunidad de hacer valer algún derecho, es decir, la seguridad jurídica tiene por expresión a la preclusividad, o lo que es lo mismo, que las situaciones de pendencia o claudicantes que pueden afectar el área de intereses personales o patrimoniales del ciudadano no se prolonguen de modo indefinido.

Como puede apreciarse, la prescripción se encuentra estrechamente vinculada con la seguridad jurídica ${ }^{19}$ permitiendo a los administrados contar con la certeza y garantía que una vez que se termine el cómputo de la prescripción, las declaraciones juradas presentadas quedarán firmes y no podrán ser modificadas por la Administración Tributaria. Esta certeza también es destacada por Bocchiardo (2003) quien señala que "el fundamento de la

19 Cabe precisar que el Tribunal Constitucional, mediante la Sentencia 016-2002-AI/TC ha indicado que si bien el principio de seguridad jurídica no se encuentra expresamente contemplado en la Constitución, de todos modos forma parte consubstancial del Estado Constitucional de Derecho. Ello, debido a que la predictibilidad de las conductas (en especial, las de los poderes públicos) frente a los supuestos previamente determinados por el Derecho, es la garantía que informa a todo el ordenamiento jurídico y que consolida la interdicción de la arbitrariedad. 
prescripción se encuentra en razones de orden público o interés social, pues el derecho requiere certidumbre, estabilidad y seguridad".

En el mismo sentido se pronuncia también Puig Brutau (1986): “(...) la prescripción extintiva encuentra su justificación en la necesidad de poner término a la incertidumbre de derechos y en la presunción de abandono por parte de su titular.”(p. 14).

Finalmente, al referirse a la prescripción y la estrecha vinculación con la seguridad jurídica, García Novoa señala:

La prescripción es una categoría general del Derecho, cuya finalidad es modular el efecto del paso del tiempo con la inactividad de quien pudiendo ejercer un derecho no lo hace. Como veremos, su fundamento radica en la seguridad jurídica, pues las pretensiones deben ejercitarse en un lapso temporal razonable no siendo aceptable que cualquier sujeto de Derecho quede indefinidamente a merced de la actuación de otro. (p. 13) (el subrayado es nuestro).

El propio García Novoa (quien ha desarrollado en extenso este tema), también se ha pronunciado sobre la importancia de la prescripción como límite temporal a la facultad de fiscalización y determinación:

(...) lo cierto es que la prescripción de la facultad de liquidar juega el día de hoy el rol de fijar el límite temporal para la conversión del importe de la autoliquidación en cuantía definitiva del tributo. (p. 30).

Lo señalado anteriormente resulta importante porque como desarrollaremos en el segundo capítulo del presente trabajo de investigación, el efecto de la prescripción, conlleva a que la Administración Tributaria se encuentra imposibilitada de fiscalizar y redeterminar la obligación que ha sido previamente determinada por el contribuyente. Así, como se mencionó en el primer acápite del presente capítulo, el término del plazo prescriptorio, hace que la determinación se vuelve definitiva ${ }^{20}$.

20 Recordemos que según la teoría desarrollada por Luis Hernández Berenguel, las características que tiene la determinación tributaria es que es única, integral y definitiva, lográndose este último aspecto cuando la Administración finaliza su revisión o cuando se cumple el plazo prescriptorio. 
En la doctrina nacional, Medrano (1994) señala lo siguiente respecto de la seguridad jurídica:

La seguridad jurídica puede identificarse con certeza y ésta se obtiene de la aplicación de una serie de principios jurídicos, cuya concurrencia permite alcanzar ese estadio en el cual los ciudadanos están siempre -razonablemente- en aptitud de conocer sus obligaciones y derechos. (p. 6)

En el Código Tributario, las acciones para determinar la obligación tributaria, para cobrar la deuda y para aplicar sanciones prescriben si es que la Administración Tributaria no ha ejercido acción alguna o, de ser el caso, si es que no se han dado supuestos de interrupción o suspensión.

Como la materia de la presente investigación es el efecto de la prescripción como límite temporal a la facultad de fiscalización y determinación de la Administración Tributaria, no desarrollaremos los supuestos de suspensión e interrupción del plazo prescriptorio previstos en los Artículos 45 y 46 del Código Tributario pues nos concentraremos en los efectos que produce una vez que éste ya se ha cumplido.

Luego del análisis efectuado a lo largo de este primer capítulo, podemos concluir que la prescripción funciona, sin duda alguna, como un límite de carácter temporal a la facultad de fiscalización y determinación de la Administración Tributaria y que una vez transcurrido el plazo prescriptorio, no es posible que se emita una Resolución de Determinación. Como ya hemos mencionado anteriormente, esta resolución es el único e idóneo acto administrativo mediante el cual la Administración Tributaria puede determinar la obligación tributaria o modificarla.

Este tema resulta relevante en la investigación pues en el segundo capítulo abordaremos, por ejemplo, qué ocurre si un contribuyente tiene un saldo a favor de un período prescrito que es arrastrado a un período no prescrito, el cual viene siendo materia de verificación por parte de la Administración Tributaria.

Además, intentaremos resolver, entre otras, las siguientes interrogantes: ¿será posible que se modifique el saldo del período prescrito (en el que ya no es posible que la 
Administración emita una Resolución de Determinación para modificarlo) a efectos de proyectar los efectos al período no prescrito? ¿qué pronunciamientos han sido emitidos por el Tribunal Fiscal sobre este tema?, entre otras.

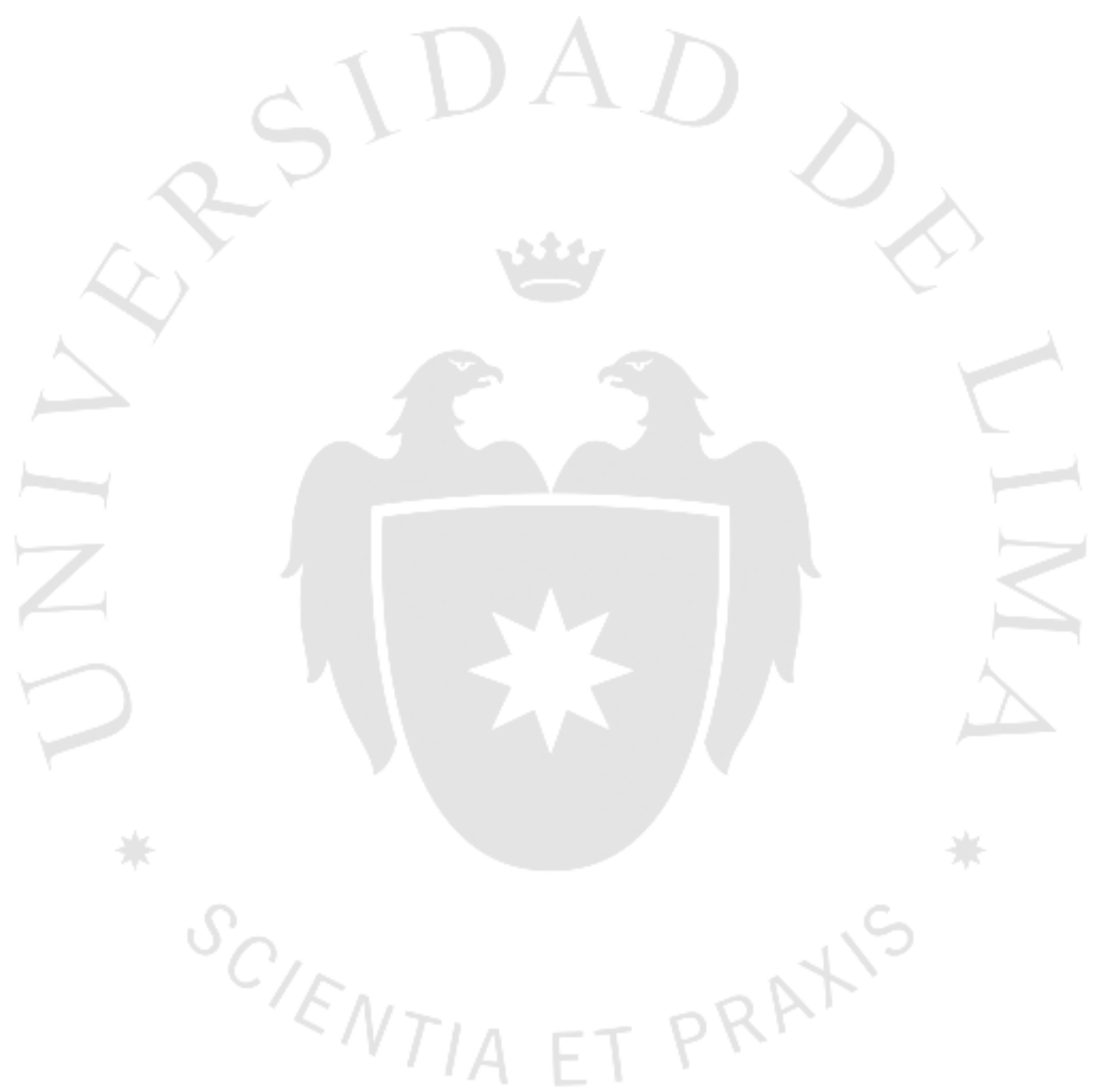




\section{CAPÍTULO II: LA PRESCRIPCIÓN COMO LÍMITE A LA FACULTAD DE FISCALIZACIÓN Y DETERMINACIÓN}

Luego de haber revisado los principales aspectos relacionados con la facultad de fiscalización y determinación tributaria y la prescripción, en el presente capítulo analizaremos cómo es que una vez cumplido el plazo prescriptorio, éste constituiría un límite temporal a las facultades con las que cuenta la Administración Tributaria.

Para ello, revisaremos diversos pronunciamientos de la SUNAT y del Tribunal Fiscal así como jurisprudencia extranjera vinculada con lo antes señalado y así conocer qué criterios son los que prevalecen en la actualidad y si ello podría conllevar al desconocimiento de los efectos que produce la prescripción.

Cabe precisar en este punto, que nuestro análisis se centrará en qué actuaciones específicas, la Administración Tributaria podría estar desconociendo los efectos de la prescripción para fiscalizar y determinar la obligación tributaria. Como sabemos, existen determinados supuestos en los que el plazo prescriptorio se ve interrumpido o suspendido y que están expresamente señalados en los Artículos 45 y 46 del Código Tributario.

En los siguientes acápites, partiremos de la premisa que ya ha finalizado el plazo prescriptorio, que no han existido supuestos de interrupción o suspensión y que el contribuyente ya ha obtenido la Resolución de Intendencia mediante la cual la Administración Tributaria ha reconocido la prescripción de su acción para determinar la obligación tributaria.

Finalmente, y a manera de conclusión, incluiremos algunas propuestas y recomendaciones que podrían ser consideradas a efectos de contar con un criterio uniforme para el reconocimiento de la prescripción como un límite a la facultad de fiscalización y determinación. 


\section{1. ¿Es posible arrastrar los efectos de un período prescrito a uno no prescrito?-}

En el presente acápite revisaremos tres situaciones en las que hemos identificado ciertos aspectos que podrían desconocer la prescripción como límite temporal a la facultad de fiscalización. Así, revisaremos si es posible que la Administración Tributaria determine la obligación tributaria de un período prescrito; luego revisaremos si es posible que se solicite información de períodos prescritos para efectuar la determinación de períodos no prescritos; y, finalmente, analizaremos el supuesto en que la Administración Tributaria efectúa una "determinación" del período prescrito para proyectar sus efectos a los períodos no prescritos (por ejemplo, saldos a favor, pérdidas de ejercicios anteriores, etcétera).

\subsection{1. ¿Qué extingue la prescripción? ¿La acción y/o el derecho?}

Respecto de esta pregunta, debemos indicar que a nivel doctrinario existe una discusión vinculada con los efectos que produce la prescripción pues un grupo de autores sostiene que se extingue la acción y el derecho; para otros solo se extingue la acción y para otros no se extingue la acción ni el derecho.

De acuerdo con lo señalado por el Artículo 63 del Código Tributario, la Administración Tributaria puede determinar la obligación durante el período de prescripción por lo que en base a ello y lo señalado en el capítulo anterior de la presente investigación, una vez que el período ha prescrito, no es posible que se efectúe una modificación a la determinación.

De acuerdo con lo señalado por el Artículo 1989 del Código Civil, la prescripción:

Extingue la acción, pero no el derecho mismo" y en la exposición de motivos sobre este artículo se menciona que "se concibe a la acción como el ejercicio del derecho ante el aparato jurisdiccional del Estado -y ésta es la que prescribe- y no la acción como elemento incorporado desligablemente a un derecho subjetivo y dependiente de él. (Revoredo de Debakev, 1985, p. 812).

En este contexto, a nivel doctrinario desde la perspectiva civil podría concluirse que lo que finalmente se ve afectado por la prescripción es la acción pero se mantiene el derecho. Así 
mismo, se sabe que la extinción de la acción y del derecho se encuentra asociada al concepto de caducidad y ésta es quizás la principal diferencia con la prescripción ${ }^{21}$.

Según lo argumentado por Hernández Berenguel, la prescripción no extinguiría ni la acción ni el derecho, "sino que más bien constituye un mecanismo de defensa del que puede hacer uso, en vía de acción o de excepción, la persona favorecida con el transcurso del tiempo para oponerse a la pretensión de quien se perjudicó con la prescripción”. (p. 33)

A la misma conclusión llega Valle Uribe, quien manifiesta que la prescripción provee un derecho de defensa materializado a través de una excepción frente a la pretensión de quien fue perjudicado con el transcurso del tiempo. (p. 79) En cambio, Caller (2005) considera que la prescripción produce únicamente la extinción de la acción (p 27), plegándose en este caso a la posición del Derecho Civil.

En nuestra opinión, la acción a la que hace referencia la norma civil podría entenderse, en el caso concreto de nuestra investigación, a la facultad que tendría la Administración Tributaria para determinar la obligación tributaria se vería extinguida al operar la prescripción de los ejercicios gravables. A diferencia del caso civil (en el caso concreto de la prescripción), en el ámbito tributario no estamos frente a una situación entre privados, sino a una relación entre el Estado y el administrado.

Es así que el Artículo 43 del Código Tributario, al que hicimos referencia en el primer capítulo de la presente investigación, señala que lo que prescribe es la acción de la Administración para determinar la obligación tributaria. Sin embargo, en este caso no existiría un derecho asociado a pesar que la Administración Tributaria (concretamente el Tribunal Fiscal) señala como argumento que el "derecho" de liquidar nuevamente los períodos prescritos se mantiene y en él se basa para validar este acto.

Sin embargo, consideramos que este argumento carece de sustento en la medida que ya no es posible ejercer la acción que reivindique el derecho (en caso se considere que éste aún tiene vigencia) de volver a determinar la obligación tributaria. Como veremos en los

21 En un trabajo de Hernández Berenguel, se identifican diferencias adicionales entre la prescripción y caducidad. Ver: Hernández Berenguel, Luis (junio 1992). "Prescripción y caducidad". En: Revista del Instituto Peruano de Derecho Tributario. $\mathrm{N}^{\circ}$ 22. Lima. p. 28. 
siguientes acápites, la Administración Tributaria pretende efectuar modificaciones en las declaraciones juradas de períodos prescritos, lo que en nuestra opinión, se contrapone con las consecuencias que se derivan de la prescripción y ello implicaría no reconocer el límite temporal de la facultad de fiscalización y determinación.

A raíz de lo mencionado anteriormente y tal como hemos mencionado en el primer capítulo, la prescripción no puede ser declarada de oficio, sino que se declara a pedido de parte. En este punto resulta interesante mencionar si es posible que exista una renuncia a la prescripción.

En estos casos, tal como señala el Código Civil en su Artículo 1991, es posible renunciar expresa o tácitamente a la prescripción ya ganada. En el caso concreto de las obligaciones tributarias, consideramos que existe una renuncia a la prescripción cuando el deudor tributario efectúa un pago a pesar de haber operado el término prescriptorio.

Sobre el particular, el Tribunal Fiscal, en la Resolución $N^{\circ} 11941$ de septiembre de 1976, menciona lo siguiente:

De los antecedentes expuestos resulta que, si bien es cierto que no se trata de un caso de interrupción de la prescripción, pues el escrito de 20 de noviembre de 1973 se presentó cuando ya ésta estaba ganada desde el 17 de octubre de 1970, nos encontramos frente a un claro caso de renuncia a la prescripción, a tenor de lo dispuesto por el Artículo 1151 del Código Civil según el cual 'se entiende renunciada la prescripción si el deudor o su heredero confiesa, sin alegar prescripción, deber y no estar pagada la deuda', desde que en el escrito antes citado, como antes se ha visto, el contribuyente que conocía la existencia y el monto de la deuda, se limitaba a solicitar el giro de 'nuevos certificados' para "poder cancelarlos".

Es importante precisar que el caso antes descrito, así como la referencia efectuada al Código Civil, podrían aplicarse en el caso del reconocimiento de deudas de períodos ya prescritos y por los cuales el deudor tributario efectúa un pago voluntario; en ese escenario, nos encontraríamos frente a un supuesto de renuncia de la prescripción.

El propio Artículo 49 del Código Tributario, respecto de este tema establece lo siguiente: "El pago voluntario de la obligación prescrita no da derecho a solicitar la devolución de lo pagado" 
No obstante, en el caso específico de la obligación tributaria de períodos prescritos, como podría ser por ejemplo, el reconocimiento de un mayor o menos saldo a favor o impuesto, consideramos que no sería posible efectuar una renuncia a la prescripción ya ganada. Consideramos que la única manera posible de modificar un saldo a favor o un impuesto determinado es con la presentación de una declaración jurada rectificatoria.

Si bien esta presentación es considerada como una causal de interrupción de la prescripción consideramos que una vez vencido el término prescriptorio, no es posible ni interrumpir ni suspender la prescripción. Este criterio ha sido recogido, por ejemplo, en la Resolución del Tribunal Fiscal Nº 13331-3-2010 que señala:

Que en cuanto a lo señalado por la Administración, en el sentido que el recurrente renunció tácitamente a la prescripción ganada al acoger las referidas deudas al REFT, debe indicarse que este Tribunal ha establecido en las Resoluciones $N^{\circ}$ 7014-2-2003 y 7891-3-2004, entre otras, que el acogimiento a fraccionamiento que incluyan períodos ya prescritos, no constituye causal que determine la pérdida del referido derecho. En tal sentido, las deudas por el Impuesto General a las Ventas de los períodos mayo, julio, agosto y octubre de 1996 se encuentran prescritas, correspondiendo revocar la apelada en este extremo.

De acuerdo a las distintas resoluciones que se analizaron sobre este tema, el hecho de presentar solicitudes de acogimiento a regímenes especiales o fraccionamiento vinculados con deudas de períodos ya prescritos no constituye una renuncia a este derecho; sin embargo debemos mencionar que en la Resolución del Tribunal Fiscal № 15470-10-2013, vinculada con este tema, existe un voto discrepante del vocal Velasquez López Raygada quien señala lo siguiente:

Que en ese sentido, resulta importante señalar que en tanto el acogimiento al fraccionamiento de deudas tributarias, regulado en el artículo 36 del Código Tributario, es un acto voluntario que involucra únicamente una solicitud para que se permita cancelar una deuda tributaria en partes, es una clara muestra que el solicitante, en ese momento, ha decidido renunciar a la prescripción y asumir su responsabilidad para cancelar una obligación que sabe que adeuda.

Que en virtud de lo expuesto, soy de opinión que en el caso de autos, la solicitud presentada por el recurrente el 26 de octubre de 2009 para acogerse al fraccionamiento regulado en el artículo 36 del Código Tributario, esto es, antes de deducir la prescripción materia de autos, 
implica una manifestación tácita de voluntad de no querer favorecerse de aquella, por lo que desde ese momento se debería iniciar un nuevo cómputo del plazo de prescripción (...).

De acuerdo con lo señalado en este voto discrepante, el hecho de presentar una solicitud de acogimiento al fraccionamiento de períodos prescritos, implica una renuncia tácita a la prescripción, conclusión con la que no concordamos pues somos de la opinión que la única posibilidad de una "renuncia" a la prescripción es efectuando el pago de una deuda ya prescrita, tal como lo señala el Código Civil.

Como conclusión de este acápite entonces, en el que se ha analizado si prescribe la acción y/o el derecho, podemos indicar que una vez transcurrido el término prescriptorio, la Administración pierde la posibilidad de efectuar una nueva determinación de la obligación tributaria, no pudiendo sustentar cualquier modificación en el hecho de conservar el "derecho" a hacerlo.

En estricto, el hecho de haber prescrito la acción implica definitivamente que las declaraciones juradas de los contribuyentes, correspondientes a períodos prescritos, no pueden ser modificadas pues la Administración Tributaria ya no cuenta con la facultad de fiscalización y determinación, no existiendo "derecho" alguno a efectuarlo. Además, no sería posible que una vez transcurrido el plazo de prescripción, los contribuyentes renuncien a este derecho mediante la presentación de una declaración jurada rectificatoria pues en nuestra opinión, el único supuesto de renuncia a este derecho es efectuar el pago de una deuda previamente determinada y cuyo derecho de cobro ya se encuentre prescrito.

\subsubsection{Solicitud de información de períodos prescritos para determinar obligaciones de períodos no prescritos.-}

En este acápite, revisaremos algunos criterios vertidos por SUNAT y por el Tribunal Fiscal, respecto de la posibilidad de solicitar información de períodos ya prescritos pero que tiene incidencia en la determinación de la obligación tributaria de períodos no prescritos. 
La SUNAT, en el año 2006, emitió el Informe $\mathrm{N}^{\circ}$ 162-2006-SUNAT/2B0000, en el que concluye lo siguiente:

La Administración Tributaria se encuentra facultada para exigir la exhibición de libros y registros contables, así como documentos y antecedentes de situaciones u operaciones ocurridas en períodos prescritos, en tanto contengan información que se encuentra relacionada con hechos que tengan incidencia o determinen tributación en períodos no prescritos materia de fiscalización.

Al respecto, debemos indicar que de acuerdo con el Artículo 87 del Código Tributario, los administrados (contribuyentes), deben facilitar las labores de fiscalización y determinación que realice la Administración Tributaria. Específicamente, en los numerales 6 y 7 del mencionado Artículo 87, se indica que los administrados deberán:

6. Proporcionar a la Administración Tributaria la información que ésta requiera, o la que ordenen las normas tributarias, sobre las actividades del deudor tributario o de terceros con los que guarden relación, de acuerdo a la forma, plazos y condiciones establecidas.

7. Almacenar, archivar y conservar los libros y registros, llevados de manera manual, mecanizada o electrónica, así como los documentos y antecedentes de las operaciones o situaciones que constituyan hechos susceptibles de generar obligaciones tributarias o que estén relacionadas con ellas, mientras el tributo no esté prescrito (...) (el subrayado es nuestro).

En la norma antes citada, se puede apreciar que el Código Tributario indica, como una limitación, que el pedido de información debe realizarse mientras el tributo no se encuentre prescrito. Ello, podría llevarnos a dos posibles interpretaciones: la primera de ellas en el sentido que la referencia "mientras el tributo no esté prescrito" se encuentra vinculada con el tributo que se está fiscalizando y, la segunda, a que dicha indicación está referida a que el tributo del período por el que se pide la información se encuentre prescrito.

En la primera de las posiciones señaladas, sería posible que la Administración Tributaria solicite antecedentes de las operaciones que tienen incidencia en la determinación de la obligación tributaria del período fiscalizado, en la medida que este último no se encuentre prescrito. Con esta interpretación, consideramos que la facultad de 
fiscalización y determinación de la Administración Tributaria sería ilimitada pues podría solicitar información de períodos prescritos pero que aún tienen incidencia en el período materia de fiscalización.

La segunda lectura de lo dispuesto por el numeral 7 del Artículo 87 del Código Tributario es que la Administración Tributaria puede solicitar antecedentes de operaciones que tengan incidencias en períodos fiscalizados en la medida que el ejercicio por el cual se solicita la información (se entiende, anteriores al períodos materia de fiscalización), aun se encuentre abierto a posibilidad de revisión, es decir, que no se encuentre prescrito. Esta posición definitivamente tiene un carácter más restrictivo respecto de la actuación de la Administración Tributaria porque solo podrá exigir información de periodos anteriores en la medida que aún no haya prescrito su facultad de fiscalización y determinación en estos ejercicios. Consideramos que ésta es la interpretación correcta a lo señalado en el numeral 7 del Artículo 87 del Código Tributario.

No obstante lo indicado anteriormente, el Tribunal Fiscal ha emitido algunos pronunciamientos que no necesariamente brindan algún alcance definitivo sobre la interpretación del Artículo 87 del Código Tributario.

Así, por ejemplo, podemos citar la Resolución del Tribunal Fiscal N 4000-1-2008, en la que al resolverse un recurso de queja, se señala lo siguiente:

Que en atención a lo expuesto la emisión de un requerimiento por parte de la Administración en el que se solicita la presentación de informes y documentación relacionada con obligaciones tributarias de períodos que el quejoso alega, se encontrarían prescritos, se encuadra en la facultad de fiscalización de la Administración y no vulnera el procedimiento establecido por el Código Tributario en tanto no se pretende determinar y cobrar obligaciones tributarias prescritas, acciones estas últimas que se plasman en correspondientes resoluciones de determinación y de multas, y en el presente caso, de la emisión del Requerimiento (...) no se puede establecer que la Administración está ejerciendo su facultad de determinar y cobrar la deuda tributaria por los años 1975 a 1999, sino que obedece a la solicitud de la Administración para que sustente los gastos familiares de los ejercicios 1995 a 1999 que según alega el recurrente se encuentran prescritos" (el subrayado es nuestro). 
En un sentido similar se pronuncia la Resolución del Tribunal Fiscal N 9508-2-2007, la cual indica que:

(...) la obligación del recurrente de conservar sólo la información y documentación contable correspondiente a tributos respecto de los cuales no haya prescrito la facultad de determinación de la Administración, prevista en el numeral 7 del artículo 87 del Código Tributario, incluye la documentación que corresponda a situaciones originadas con anterioridad al ejercicio fiscalizado pero que guardan una relación, directa, lógica y temporal con la determinación de la obligación tributaria (...)

Como vemos en estas Resoluciones, el Tribunal Fiscal valida que la Administración Tributaria solicite información de períodos prescritos por entender que esta solicitud no constituye una determinación de estos períodos. No obstante, es importante destacar aquí que la Única Disposición Final de la Ley $\mathrm{N}^{\circ} 27788^{22}$ (mediante la cual se derogó el Artículo 81 del Código Tributario, vinculado con la suspensión de la fiscalización), precisa que la facultad de fiscalización, en lo que respecta a la prescripción, se regula por el Artículo 43 del Código Tributario; es decir, bajo los mismos plazos y parámetros que para la facultad de determinación. Además, recordemos que la finalidad de un procedimiento de fiscalización es la determinación de la obligación tributaria por lo que consideramos que el Tribunal Fiscal no debió validar la solicitud de la Administración.

Este concepto es recogido también por Fernández Cartagena (2004), quien al analizar los efectos de la prescripción, señala:

La prescripción de la acción del Fisco para determinar la deuda implica la prescripción de las acciones de fiscalización, pues dicha facultad tiene como finalidad que la Administración recabe la información necesaria para determinar la deuda. (...) Por ello, la prescripción de la determinación impide a la Administración fiscalizar y determinar la obligación tributaria del período respectivo.

Este planteamiento ha sido recogido por el Tribunal Fiscal quien señala que (...) 'la facultad de fiscalización estará sujeta a los plazos de prescripción señalados en el artículo 43 del Código Tributario en función de la obligación tributaria que, a través de ella, se

22 Publicada el 25 de julio de 2002. 
pretende determinar (y cobrar), con prescindencia de si los hechos y situaciones que están siendo fiscalizados por incidir en la determinación de dicha obligación se produjeron en un período distinto al que ésta corresponde, lo que se pone de manifiesto por el hecho que los plazos de prescripción que establece el Código Tributario toman como punto de referencia el nacimiento y la exigibilidad de la obligación tributaria, haciendo explícita la vinculación entre la facultad de fiscalización y el tributo y período materia de determinación (y cobro)'

Lo manifestado por el Tribunal Fiscal no es sino una aplicación de la Ley $\mathrm{N}^{\circ} 27788$ publicada el 25 de julio de 2002, la que dispone que la fiscalización está sujeta a los plazos de prescripción establecidos en el artículo 43 del Código Tributario. Es decir, la mencionada norma ratifica que el plazo de prescripción de la acción para fiscalizar es el mismo que el de la acción para determinar. Y no puede ser de otra manera pues la facultad de fiscalizar está íntimamente ligada a la facultad de determinar. Si el Fisco no tiene la posibilidad de determinar, menos aún puede fiscalizar. La fiscalización no es un fin en sí misma, es un medio para determinar la deuda. Por esta razón prescribe esta acción cuando prescribe la acción del Fisco para determinar la deuda. (p. 6).

Otro de los pronunciamientos del Tribunal Fiscal sobre este tema, lo encontramos en la Resolución $\mathrm{N}^{\circ}$ 100-5-2004, mediante la cual se resolvió un caso vinculado con la determinación del Impuesto a la Renta del ejercicio 1999; para esta determinación, la Administración Tributaria verificó una operación producida en el ejercicio 1996 (que ya se encontraba prescrito) vinculada con una revaluación de activos. Este tema tenía incidencia en el ejercicio 1999 en la medida que el contribuyente había considerado la depreciación del ejercicio en función del costo computable determinado en el ejercicio 1996, el cual, a criterio de la Administración Tributaria, era mayor al que le correspondía.

Luego de efectuar el análisis del caso, el Tribunal Fiscal concluye lo siguiente:

Que en efecto, en el presente caso la verificación del informe de tasación de los activos fijos que fueron transferidos a la recurrente con motivo de la fusión, no originó una determinación de deuda tributaria en el ejercicio 1996, sino que incidió sobre la determinación del Impuesto a la Renta de 1999, por lo que teniendo en cuenta que conforme con la conclusión arribada en los considerando precedentes, a la facultad de fiscalizar le resultan aplicables los plazos previstos para las deudas tributarias de los períodos que está 
determinando, el plazo de prescripción a considerar sería el aplicable al Impuesto a la Renta del ejercicio 1999.

Que, en ese sentido, la posibilidad de la Administración de verificar el informe de tasación de los activos fijos que fueron transferidos a la recurrente con motivo de la fusión se encuentra amparada en el hecho que la facultad de fiscalizar el ejercicio 1999 aún no había prescrito, y no en la modificación o revocación de la Resolución de Determinación $\mathrm{N}^{\circ}$ 012-03-0001548 (emitida por el Impuesto a la Renta del ejercicio 1996 y que no es materia del presente expediente) (...).

Como podemos apreciar, el Tribunal Fiscal indica que a pesar que el período se encuentre prescrito, la Administración Tributaria puede solicitar información en la medida que tengan influencia en la determinación del período no prescrito; ello, resultaría en nuestra opinión, una clara contradicción a lo dispuesto por el Código Tributario.

Uno de los principales ejemplos sobre información que puede repercutir en períodos siguientes es la depreciación de activos. Como sabemos, los activos fijos de la empresas pueden ser depreciados en función de determinados requisitos y determinadas tasas señaladas en la Ley del Impuesto a la Renta ${ }^{23}$; así, por ejemplo, los inmuebles se deprecian en 20 años, mientras que los vehículos (si se aplica la tasa máxima del 20\%) se deprecian en 5 años, etcétera.

Con lo antes indicado, los contribuyentes deberían conservar información que se encuentre vinculada con la obligación tributaria en la medida que el tributo no se encuentre prescrito; así, si se adquiere un inmueble en 2010, la Administración podría pedir información de este ejercicio en el año 2029 para determinar si la depreciación consignada en este ejercicio es correcta.

En nuestra opinión, si bien la norma ampararía este posible pedido de SUNAT, ello resulta irracional pues implica que los contribuyentes conserven información durante un largo período. En este aspecto compartimos la posición que adopta Medrano (2005) al analizar una situación similar:

23 Ver artículos 38 y siguientes de la Ley del Impuesto a la Renta y el Artículo 22 del Reglamento de la Ley del Impuesto a la Renta. 
La cuestión puede resultar aún más ardua en aquellos países cuya legislación faculta a los contribuyentes para destruir la documentación relativa a ejercicios prescritos. En este supuesto, es claro que la Administración no podría obligar a exhibir documentos que el sujeto tenía derecho a eliminar (aunque no lo hubiera ejercido) porque si otro contribuyente, en la misma condición, hubiera destruido los elementos sustentatorios, no podría ser revisado. (p. 16).

En el mismo sentido, Bravo Cucci (2006) señala:

En cuanto a la interpretación que efectúa el Tribunal Fiscal, respecto a que la obligación de conservar la documentación contable durante el plazo de prescripción, implica también la de mantener aquella que corresponda a períodos prescritos pero que tengan incidencia a períodos no prescritos, debemos señalar que la misma excede del texto y sentido de la norma interpretada, pues de acuerdo a ella, dicha obligación se mantiene sólo mientras la obligación tributaria no esté prescrita. (párr.. 5)

Resulta importante señalar que la Resolución del Tribunal Fiscal № 100-5-2004 que hemos mencionado anteriormente, fue objeto de una demanda contencioso administrativa que llegó a tener un pronunciamiento en la vía judicial. Así, la Sala Constitucional y Social de la Corte Suprema de Justicia, mediante la Sentencia de Casación 1136-2009) indicó que:

(...) queda claro que la llamada verificación de operaciones de ejercicios prescritos no es otra cosa que pretender fiscalizar los mismos (...).

(...) por lo que resulta correcta la interpretación realizada por la Sala Suprema revisora del artículo 43 del Texto Único Ordenado del Código Tributario, dado que la reapertura de una nueva fiscalización, por un periodo ya fiscalizado, debería hacerse dentro del plazo de prescripción y no fuera de este como ha ocurrido en el presente caso, siendo esta una interpretación correcta del tantas veces citado artículo.

El Poder Judicial, en nuestra opinión, adopta un criterio correcto, reconociendo los efectos de la prescripción sobre la facultad de fiscalización y determinación de la Administración Tributaria. Así, se deja en claro que la referida facultad tiene un límite temporal y no es posible modificar la obligación tributaria de un período prescrito. 
Este tema (aunque llegando a una posición algo más conservadora) también ha sido abordado anteriormente por el Grupo Peruano de la Asociación Fiscal Internacional (IFA), pues en las VIII Jornadas Nacionales de Tributación, concluyeron lo siguiente:

Que tratándose de operaciones realizadas y, en su caso, contabilizadas, que no han sido objeto de reparo en la fiscalización de un período ya prescrito, la Administración Tributaria debe estar impedida de formular reparos respecto de las consecuencias tributarias que tales operaciones produzcan en períodos no prescritos. $^{24}$

La recomendación realizada, podría llevarnos a interpretar que, en la medida que el período prescrito no haya sido materia de fiscalización, la Administración Tributaria sí podría solicitar información de operaciones de dicho período para revisar las consecuencias de estas operaciones en el período no prescrito; es decir, si la Administración Tributaria ya tuvo la posibilidad de revisar las operaciones de dicho período, no tendría sentido que solicite nuevamente información cuando ya se tiene una determinación definitiva por tal ejercicio.

No compartimos del todo tal posición porque consideramos que el hecho que el ejercicio ya haya sido fiscalizado tiene los mismos efectos prácticos a que haya prescrito la acción de la Administración para determinar la obligación tributaria; esto es, la imposibilidad de modificar la determinación efectuada por el contribuyente (que por efecto de la prescripción pasa de ser una liquidación temporal o sujeta a revisión a una definitiva) o, de ser el caso, la que consta en la Resolución de Determinación en caso el ejercicio haya sido fiscalizado.

Finalmente, debemos mencionar que en una reciente resolución, el Tribunal Fiscal ha adoptado una interesante posición sobre el alcance del artículo 87 del Código Tributario. Así, en la Resolución del Tribunal Fiscal N 3926-1-2014, se indica lo siguiente:

Que si bien, tal como está redactado el numeral 6 del mencionado artículo 87 del Código Tributario, podría interpretarse que no existe límite alguno para los requerimientos de información de la Administración Tributaria, el mencionado dispositivo legal debe

${ }^{24}$ Revisar la Recomendación 17 de la Resolución de las VIII Jornadas Nacionales de Tributación de la Asociación Fiscal Internacional. Grupo Peruano - Las Facultades de Fiscalización y Determinación de la Administración Tributaria. 
interpretarse necesariamente a la luz del artículo 74 de la Constitución, por lo cual la potestad tributaria se ejerce respetando los derechos fundamentales y principios establecidos en la Constitución, como el principio de seguridad jurídica, que es el fundamento de la prescripción. (...)

Que en consecuencia, (...) al haber prescrito la facultad de fiscalización de la Administración respecto del Impuesto a la Renta del ejercicio 2006, la recurrente no tenía la obligación de presentar la información solicitada (...), dado que ya no tenía la obligación de conservar la documentación que le permitiera determinar si existía o no la anotada vinculación económica (...).

Que con relación a lo argumentado por la Administración respecto al deber de colaboración, cabe indicar que dicho deber no resulta aplicable al caso de autos en los términos expuestos por ésta, dado que de acuerdo a lo señalado anteriormente, si bien la Administración se encuentra facultada a requerir a terceros documentos, relacionados con hechos que determinen tributación, en la forma y condiciones solicitadas, la que incluye la facultad de requerir la información destinada a identificar a los cliente y consumidores del tercero, dicha facultad se encuentra limitada por el plazo de prescripción, según ha sido expuesto, siendo que de aplicar dicho deber de colaboración conforme lo indica la Administración, se estaría desconociendo el límite impuesto por el ordenamiento jurídico tributario a la facultad de fiscalización de la Administración referido al plazo prescriptorio" (el subrayado es nuestro).

Resulta evidente que mediante esta resolución, el Tribunal Fiscal reconocería la importancia de la prescripción como un límite no solo para determinar la obligación tributaria, sino también para la solicitud de información vinculada con periodos prescritos.

Así, el Tribunal Fiscal adoptaría posición que mencionamos anteriormente en el sentido que solo se podrá solicitar información de períodos que aún se encuentren sujetos a fiscalización.

\subsubsection{Determinación de la obligación tributaria de períodos prescritos.-}

Como se ha señalado en el primer capítulo de la presente investigación, la facultad de fiscalización y determinación no puede ser ejercida por la Administración Tributaria de 
manera irrestricta. Así, pudimos identificar que el reconocimiento a los derechos fundamentales de los ciudadanos y el término del plazo de prescripción actúan como límites a esta facultad; siendo reconocido este último como un límite temporal.

En este sentido, resulta importante delimitar hasta qué punto la Administración Tributaria puede efectuar la revisión y una nueva determinación de la obligación tributaria si es que nos encontramos en un período prescrito. Por lo que hemos analizado hasta aquí, la prescripción actúa como un límite temporal a esta facultad por lo que la determinación de la obligación tributaria realizada por los contribuyentes, adquiere el carácter de invariable y definitiva, no siendo posible que se liquide nuevamente.

Incluso, debemos indicar que la Administración Tributaria debería reconocer cada uno de los conceptos incorporados en la declaración jurada de un ejercicio que ya prescribió, incluso si estos forman parte de la declaración de un período no prescrito que se encuentre en revisión o fiscalización.

Si bien desarrollaremos casos específicos en los siguientes acápites, resulta importante citar lo señalado por García Novoa (2011b) sobre este tema:

(...) no cabe admitir que lo que prescribe es el derecho a liquidar y que la posibilidad de comprobar permanece incólume. Por el contrario, y en virtud de que la comprobación está, en principio, orientada a liquidar, debe entenderse que la pérdida de la facultad de liquidar por la prescripción, debe conllevar la pérdida de la posibilidad de comprobar.

En suma, si no se comprobó el período en el que supuestamente se generó la base negativa, la misma no podrá comprobarse cuando su elemento negativo se incorpore a la base de otra obligación, si la base negativa incorporada procede de un período prescrito. Lo contrario sería tanto como admitir que la facultad de liquidar (que no tiene que derivar en una liquidación positiva de la deuda sino que también puede desembocar en una cuantificación negativa pues la liquidación es el conjunto de actividades realizadas por la Administración hasta la etapa de recaudación) una vez prescrita, puede rehabilitarse por el mero hecho de resultar incorporada, como elemento de cuantificación, a una deuda tributaria respecto a la cual el derecho a liquidar no ha prescrito todavía. (p. 49) 
En este sentido, compartiendo la posición adoptada por César García Novoa, resulta claro que la Administración Tributaria, una vez que ha concluido el término prescriptorio, no puede ejercer su facultad de fiscalización (comprobación) y determinación (cuantificación), incluso cuando se incorporen elementos del período prescrito a uno no prescrito.

\subsubsection{Consecuencias en períodos posteriores de la "determinación” de períodos prescritos.-}

En el presente acápite revisaremos si es posible que la Administración Tributaria modifique la determinación de un período ya prescrito para proyectar sus efectos a períodos no prescritos, por ejemplo, en los casos de saldos a favor o pérdidas arrastrables.

En primer lugar debemos indicar que de acuerdo con lo señalado por el Artículo 57, cada ejercicio gravable es independiente de otro, lo que genera el denominado principio de autonomía de los ejercicios fiscales. Este principio no contiene excepción alguna en el sentido que los efectos de un período prescrito pueden incidir en un período no prescrito. Así, en nuestra opinión, el efecto jurídico que se genera es que los importes contenidos en una autodeterminación, deben ser incorporados tal cual a las determinaciones de los períodos no prescritos.

Esta posición, en el sentido que los ejercicios gravables son independientes, se encuentra confirmada por la Resolución del Tribunal Fiscal N 4971-2-2009, en la que se señala lo siguiente:

Que el recurrente sostiene que la resolución apelada no tomó en cuenta el plazo de interrupción de la prescripción ni que ésta no puede ser declarada de oficio, sino a solicitud de parte, de conformidad con lo dispuesto por los artículos 45 y 47 del Código Tributario.

Que de la revisión de la declaración del Impuesto a la Renta del ejercicio 1999 se aprecia que el recurrente no obtuvo ingresos en el ejercicio 1999 por lo que el saldo a favor declarado por la suma de S/. 910.00 en ese ejercicio provenía del ejercicio anterior (1998), el que se mantuvo en el ejercicio 1999, materia de la solicitud de devolución. En tal sentido, para efecto de establecer la procedencia de la solicitud de devolución 
corresponde a continuación analizar la declaración jurada del Impuesto a la Renta del ejercicio 1998.

Como vemos, el Tribunal Fiscal indica claramente que para revisar el importe del saldo, necesariamente debe efectuar la revisión del ejercicio anterior, no pudiendo efectuarlo sin respetar la independencia de cada ejercicio.

Al respecto y como hemos sostenido a lo largo de esta investigación, solo mediante una resolución de determinación es posible que la Administración Tributaria determine la obligación tributaria. Evidentemente, este acto administrativo solo puede ser emitido por períodos que no se encuentran prescritos pues una vez concluido el plazo prescriptorio, la Administración Tributaria no puede determinar obligación tributaria alguna.

Por ello, resulta importante en primer lugar, determinar qué entendemos por obligación tributaria y si ésta incluye a los saldos a favor de períodos anteriores o si únicamente se encuentra referido al importe que resulta de aplicar la tasa del impuesto a la renta neta del contribuyente.

En nuestra opinión, la obligación tributaria incluye tanto las pérdidas tributarias como los saldos a favor de ejercicios anteriores; es decir, esta obligación no puede ser entendida únicamente como el tributo por pagar antes de la aplicación de los créditos tributarios que reconoce la propia legislación. Desconocer estos importes y no considerarlos como parte de la obligación tributaria distorsionaría por completo su concepto.

La posición adoptada se sustenta, principalmente en lo señalado por la Exposición de Motivos del Decreto Legislativo $\mathrm{N}^{\circ} 953^{25}$, en la que se indica que la obligación tributaria incluye la totalidad/de créditos que reconoce la legislación. Así, cuando el Artículo 43 del Código Tributario hace referencia a la "obligación tributaria", ésta comprende, entre otros, el saldo a favor o las pérdidas tributarias.

25 El Decreto Legislativo $N^{\circ} 953$ fue publicado el 5 de febrero de 2004 e introdujo una serie de modificaciones al Código Tributario. 
En la mencionada Exposición de Motivos se indica: "Se precisa que el plazo de prescripción está referido a la determinación de la obligación tributaria, en la medida que comprende tanto la determinación del tributo a pagar como de saldos, créditos o similares.”

En este orden de ideas, si la Administración Tributaria pretendiese modificar un saldo a favor de un ejercicio prescrito para proyectar sus efectos a períodos no prescritos, sin la emisión de una Resolución de Determinación (lo cual no sería posible en la medida que se trata de un ejercicio en el que ya prescribió la acción de la Administración para determinar), implica una indebida modificación de la obligación tributaria. Es así que consideramos que si la Administración Tributaria modifica un saldo de un período prescrito, está efectuando una nueva determinación de la obligación tributaria, a pesar que se encuentra impedida de hacerlo.

Es importante mencionar también que la imposibilidad de modificar los saldos determinados por los contribuyentes, tiene como fundamento que el objetivo que debe perseguir la Administración Tributaria no es solo determinar deuda tributaria, sino también, de ser el caso, determinar la existencia de un crédito o saldo a favor del contribuyente. Ello se confirma, además, con la modificación al Artículo 43 del Código Tributario, efectuada mediante el Decreto Legislativo $\mathrm{N}^{\circ} 953$ que ya hemos mencionado pues antes de la modificación, la norma hacía referencia a "deuda tributaria" y fue modificada por "obligación tributaria" aunque precisando que ambos conceptos incluían a los saldos o créditos a favor.

Al respecto, se ha pronunciado la Resolución del Tribunal Fiscal N³859-2-2003, la misma que indica:

(...) cuando los artículo 27 y 43 del Código Tributario se refieren a la prescripción de la acción de la Administración para 'determinar la deuda tributaria', dicha acción debe entenderse conforme con lo establecido por el Capítulo II del Título II el Libro Segundo del Código Tributario y no según lo dispuesto por el artículo 28 referido a los componentes de la deuda tributaria, por lo que aún en el $\underline{\text { caso de que no existiera tributo a pagar en la autoliquidación efectuada por la recurrente, sino como }}$ en el caso de autos un saldo a favor, la recurrente tenía el derecho de solicitar se declare la prescripción respecto del Impuesto a la Renta del ejercicio 1995. (El subrayado es nuestro). 
Sobre esta resolución, debemos señalar que la referencia al Capítulo II del Código Tributario incluye la necesidad de emitir una Resolución de Determinación en caso se pretenda modificar la deuda tributaria, incluso en el caso que exista una saldo a favor que debe ser reconocido y no limitándolo al tributo, multa e intereses (componentes de la deuda tributaria según lo dispuesto por el Artículo 28 del Código Tributario).

Así mismo, la Resolución del Tribunal Fiscal № 6753-2-2003, luego de referenciar lo señalado en la Resolución $N^{\circ} 3859-2-2003$, citada anteriormente, concluye:

Que en tal virtud, por la prescripción se entiende también extinguida la acción de la Administración para determinar los créditos tributarios.

\section{$(\ldots)$}

Que en ese sentido, encontrándose vencidos los referidos términos prescriptorios a la fecha de notificación de los valores impugnados, y no habiéndose acreditado en autos que se haya producido alguna de las causales de interrupción o suspensión previstas en los artículos 45 y 45 del Código Tributario, la prescripción alegada por la recurrente resulta procedente" (el subrayado es nuestro).

Así mismo, el criterio antes señalado también es recogido por la Resolución del Tribunal Fiscal N ${ }^{\circ}$ 17268-3-2011, la que señala:

(...) resulta claro que la determinación de la obligación tributaria no involucra necesariamente que su resultado arroje siempre la existencia de un importe a pagar al Estado, habida cuenta que por efectos de aplicación de las normas que regulan cada tributo, aun cuando al determinarse ésta se estableciere la existencia de una de un pago indebido o en exceso realizado previamente y arrojar como resultado la existencia de un saldo a favor del contribuyente.

Finalmente, para sustentar nuestra posición resulta importante señalar que la determinación de la obligación tributaria (la misma que incluye los créditos), debe ser realizada mediante un acto formal. Así, el contribuyente debe cumplir con la formalidad de presentar su declaración con carácter de declaración jurada y la Administración Tributaria, debe cumplir con los requisitos formales establecidos en el Código Tributario y respetar los principios de los actos administrativos (bajo sanción de nulidad). 
El Tribunal Fiscal mediante la Resolución N 591-3-99, indicó la necesidad de emitir una Resolución de Determinación si es que realiza modificaciones a lo declarado por el contribuyente, a pesar que en el caso concreto se había emitido un acto administrativo (Orden de Pago):

Que de lo anteriormente expuesto, puede apreciarse que la Administración Tributaria ha considerado, a efectos de determinar la omisión por el Impuesto General a las Ventas correspondiente a los meses de setiembre de 1996, enero, febrero y abril de 1997, el débito declarado por el propio contribuyente en dichos períodos por las ventas y adquisiciones gravadas; sin embargo, ha desconocido parte del monto consignado por crédito fiscal en el mes de abril de 1997, como también el monto declarado por saldo a favor del período anterior en los meses de enero, febrero y abril de 1997, dando lugar al cobro por las diferencias que se consignan en sus Órdenes de Pago materia del presente análisis.

Que consecuentemente la Administración Tributaria ha efectuado reparos al tributo lo cual solo puede estar sustentado en una Resolución de Determinación, conforme se preceptúa en el artículo 76 del Código Tributario ya citado. (El subrayado es nuestro).

Es así que no sería posible que mediante un acto distinto a una Resolución de Determinación, la Administración Tributaria pretenda modificar la obligación tributaria de períodos prescritos. En la práctica, lo que realiza la Administración Tributaria para modificar la determinación de períodos prescritos es incluir un anexo con la nueva liquidación y la incluye como parte de la Resolución de Determinación del período no prescrito.

Esta posición también ha sido adoptada en la Resolución del Tribunal Fiscal $N^{\circ}$ 3093-3-2008:

Que de lo expuesto se advierte que la Administración ha procedido a reliquidar el saldo a favor del ejercicio 1996, desconociendo el monto considerado por la recurrente en la declaración jurada correspondiente a dicho ejercicio, lo cual debió estar sustentado en una resolución de determinación, conforme se preceptúa en el artículo 76 del Código Tributario y de acuerdo al criterio que ha sido establecido por este Tribunal en diversas resoluciones, entre otras, las Resoluciones No. 591-3-99 y 192-1-2003. 
Este actuar, consideramos, no convalida, de modo alguno, la modificación de la obligación tributaria del período prescrito pues la Administración Tributaria debería respetar la determinación efectuada por el contribuyente que ya adquirió el carácter definitivo con la prescripción.

En un sentido similar se pronuncia la Resolución del Tribunal Fiscal $N^{\circ}$ 4651-32010, la cual indica:

Que de acuerdo a lo señalado en los párrafos precedentes, la Administración mediante la resolución recurrida modificó los saldos a favor declarados por la recurrente en los ejercicios 1995 y 1996, respecto a lo cual se sebe señalar que si bien es cierto dicha facultad le es conferida por el artículo 61 del Código Tributario, la misma debe ejercerse, mediante la emisión de un acto administrativo idóneo, cual sería una resolución de determinación emitida al amparo de lo establecido por el artículo 77 del Código Tributario, en la cual se explique los motivos o circunstancias por los cuales se efectúa tal modificación, condición que no se ha producido en el caso de autos, pues no se ha emitido resolución alguna modificando la determinación efectuada por la recurrente en los citados ejercicios 1995 y 1996, observándose además que respecto de estos la facultad de la Administración para efectuar la determinación de la obligación tributaria habría prescrito, ello a tenor de lo dispuestos en los artículos 43 y 44 del Código Tributario.

(...) Que en ese orden de ideas, teniendo en cuenta lo señalado por la Administración en la resolución recurrida en cuanto a que la recurrente no tiene deuda por concepto del Impuesto a la Renta del ejercicio 1996, corresponde que a efecto de establecer el Impuesto a la Renta del año 1997 se aplique el saldo a favor del ejercicio anterior declarado por la recurrente (...). (El subrayado es nuestro).

Finalmente, mencionaremos lo que señala la Resolución del Tribunal Fiscal N ${ }^{\circ} 10322-11$ 2012. En ésta, se resuelve un pedido de aclaración efectuado por el contribuyente en la medida que la Administración Tributaria había realizado una nueva determinación del ejercicio 2000, modificando el saldo a favor del ejercicio 1999 aunque este último se encontraba prescrito.

El Tribunal Fiscal concluye lo siguiente: 
Que de lo expuesto en el considerando anterior se tiene que si bien este Tribunal, mediante la Resolución $\mathrm{N}^{\circ}$ 06671-11-2012, estableció los lineamientos que la Administración debía considerar para efectuar la determinación de los pagos a cuenta del Impuesto a la Renta del ejercicio 2000, dicho pronunciamiento se efectuó cuando aún no se había emitido la Resolución de Intendencia N ${ }^{\circ}$ 011-020-000323/SUNAT de 4 de mayo de 2012, que declaró prescrita la acción de la Administración para determinar la obligación tributaria y exigir el pago del Impuesto a la Renta del ejercicio 1999, razón por la cual corresponde declarar infundada la solicitud de aclaración presentada en tal extremo.

Que no obstante lo indicado, ya que con posterioridad a la Resolución $\mathrm{N}^{\circ} 06671$ 11-2012 materia de aclaración, se emitió la citada Resolución de Intendencia No. 011020-000323/SUNAT, dicha prescripción podrá ser deducida por la solicitante en caso la Administración modifique la determinación de la deuda tributaria contenida en la declaración jurada presentada por el Impuesto a la Renta del ejercicio 1999 y sus efectos posteriores" (el subrayado es nuestro).

Como puede apreciarse, resulta claro que el Tribunal Fiscal adoptó en las resoluciones antes señaladas, ha reconocido la importancia de la emisión del acto administrativo idóneo a efectos de modificar la determinación efectuada por los contribuyentes, aunque limitándolo al plazo de prescripción. Caso contrario, la Administración Tributaria deberá considerar los importes declarados por los contribuyentes.

También asumiendo el mismo criterio, la Resolución del Tribunal Fiscal N 2189-32002 señala lo siguiente:

(...) de conformidad con lo dispuesto por el Artículo 88 de la Ley del Impuesto a la Renta y el artículo 52 de su Reglamento, los pagos a cuenta efectuados y los saldos a favor establecidos por el propio responsable en su declaración jurada constituyen crédito contra el Impuesto a la Renta.

$$
(\ldots)
$$

Que este Tribunal en diversas resoluciones, tal como la No. 1257-5-97, ha señalado que el desconocimiento por parte de la Administración de los créditos considerados por la 
recurrente a efecto de determinar el Impuesto a la Renta, constituye una modificación de la autoliquidación efectuada por la recurrente en su respectiva declaración.

Así, del análisis de las resoluciones antes señaladas, podemos concluir que la Administración Tributaria podría modificar la obligación tributaria determinada por un contribuyente mediante una Resolución de Determinación, entendiéndose que dentro del concepto de obligación tributaria se encuentran incluidos los saldos a favor, créditos y pérdidas de ejercicios anteriores.

Consideramos además que dicha conclusión será aplicable únicamente en la medida que el período por el cual la Administración Tributaria emita la Resolución de Determinación por la que se modifica la obligación tributaria del contribuyente, corresponda a un ejercicio en el que aún no ha vencido el término prescriptorio para la facultad de fiscalización y determinación.

\subsubsection{Primer caso: Modificación de la determinación de un período prescrito para}

\section{proyectar sus efectos a uno no prescrito en el Impuesto a la Renta.-}

Como hemos mencionado anteriormente, en la Resolución del Tribunal Fiscal $\mathrm{N}^{\circ} 10322$ 11-2012, se reconoce que la prescripción no solo se limita a la determinación del ejercicio sino también a "los efectos posteriores", entendidos estos como la proyección que podría realizar la Administración Tributaria en los ejercicios siguientes.

No obstante el criterio antes señalado, también debemos precisar que en los últimos años el Tribunal Fiscal ha emitido una serie de resoluciones (que analizaremos a continuación) en las que validaría que sí es posible que la Administración Tributaria efectúe una nueva determinación de un período prescrito para proyectar sus efectos a períodos no prescritos.

Por ejemplo, en la Resolución del Tribunal Fiscal N 13365-3-2013, mediante el cual se resuelve un caso similar al que fue materia de pronunciamiento en la Resolución $\mathrm{N}^{\circ}$ 10322-11-2012, antes citada, indicó: 
Que respecto de la prescripción opuesta por la contribuyente, si bien es cierto de conformidad con el artículo 48 del Código Tributario, ésta puede efectuarse en cualquier estado del procedimiento administrativo o judicial, también lo es que el Impuesto a la Renta del ejercicio gravable 1999 no ha sido materia de la resolución cuya resolución de cumplimiento constituye materia de grado; circunstancia que no queda desvirtuada por el hecho que, por la propia naturaleza del Impuesto a la Renta que considera ejercicios gravables que coinciden con el año calendario, en los ejercicios 2000 y 2001 pudieran existir saldos de años anteriores, que afecten la determinación de la deuda tributaria.

Con el mismo criterio, la Resolución $N^{\circ}$ 01395-1-2013, al analizar una reliquidación de períodos prescritos efectuada por SUNAT concluyó:

Que sobre el argumento consistente en que la reliquidación efectuada ha sido realizada tomando en cuenta períodos prescritos, cabe indicar que conforme al criterio establecido en la Resolución $\mathrm{N}^{\circ}$ 00100-5-2004, la prescripción como meca mismo de defensa solo acarrea la imposibilidad de fijar el monto de la deuda tributaria del ejercicio prescrito, en conclusión, la Administración podía reliquidar dicho período en la medida que ello generaba consecuencias para la determinación del Impuesto a la Renta del ejercicio 2002, por lo que lo argumentado en contrario carece de sustento" (el subrayado es nuestro).

Otra de las resoluciones que es referida en diversa jurisprudencia del Tribunal Fiscal es la Resolución $\mathrm{N}^{\circ}$ 0322-1-2004, en la que se analiza la posibilidad que la Administración realice verificaciones de un ejercicio prescrito:

(...) la prescripción como mecanismo de defensa, solo acarrea la imposibilidad de fijar el monto de la deuda tributaria del ejercicio prescrito, sin que ello implique la validación de los efectos tributarios de las operaciones realizadas.

Que teniendo en cuenta los conceptos señalados, la Resolución en referencia, indica que no cabe entender que las verificaciones efectuadas por la Administración implicaron un procedimiento de fiscalización del ejercicio 1996 y una determinación de la obligación tributaria del mismo período, sino únicamente una revisión o verificación de la revaluación voluntaria efectuada por la recurrente con motivo de la fusión, tendiente a establecer si el costo computable de los activos con ocasión de éste era correcto, con la finalidad de trasladar sus consecuencias al ejercicio 1999 
Que conforme al criterio expuesto por este Tribunal en la Resolución N 00100-52004 en referencia, en el presente caso cabe concluir que la Administración se encontraba facultada para verificar la revaluación de los activos transferidos a la recurrente como resultado de la escisión llevada a cabo (...) en el ejercicio 1996, dado que la misma generaba consecuencias para la determinación del Impuesto a la Renta del ejercicio 1999” (el subrayado es nuestro).

Al respecto, consideramos incorrecta la conclusión a la que llega el Tribunal Fiscal en estos casos pues efectuar una verificación de la situación tributaria de un ejercicio prescrito, constituye un acto efectuado al amparo de la facultad de fiscalización con la que cuenta la Administración Tributaria y si ésta verificación implica una modificación de aquella situación, constituye en nuestra opinión una nueva determinación.

Respecto de la jurisprudencia de otros países, debemos comentar que el Tribunal Fiscal peruano, al resolver un caso vinculado con prescripción (y que ya mencionamos anteriormente), hace referencia a una jurisprudencia argentina. Así, en la Resolución $\mathrm{N}^{\circ}$ 100-5-2004, se cita la Resolución del Tribunal Fiscal argentino del 8 de mayo de 1997, emitida por la Sala B, en la que se concluye que:

(...) no debe confundirse el instituto de la prescripción que afecta a las acciones y poderes del Fisco para determinar y exigir impuestos con la facultad de verificar que se extiende más allá de aquél período y que si bien el Fisco no puede exigir un impuesto en relación a un año prescrito, puede, en cambio, proyectar aquellos resultados en un período no prescrito mediante la modificación de un concepto que se encuentra vinculado directa, lógica y temporalmente con el hecho verificado (ej. Amortizaciones) o incluso rectificar la declaración jurada de un año no prescrito cuando se hacen incidir en los mismos ajustes de las de años prescritos corregidos sucesivamente hasta su exteriorización en aquella rectificación. ${ }^{26}$ (El resaltado es nuestro).

Al respecto, debemos manifestar que no coincidimos con la posición adoptada por el Tribunal Fiscal argentino y que forma parte de los sustentos del Tribunal Fiscal peruano pues en estos casos se está aceptando que la Administración Tributaria puede modificar los

26 Revisar página 9 de la Resolución del Tribunal Fiscal N $100-5-2004$ 
conceptos o reparos de un período no prescrito para proyectar sus efectos a un período no prescrito. Ello, definitivamente, altera la seguridad jurídica de los contribuyentes y desconoce los efectos de la prescripción como un límite temporal. Además, como se ha revisado en esta investigación, para efectuar la modificación señalada, se debería emitir una Resolución de Determinación, la misma que es imposible emitir respecto de un período en respecto del cual ya prescribió la acción de la Administración Tributaria para determinar la obligación tributaria.

No obstante, es importante señalar que en Argentina existe una norma que facultaría a la Administración Tributaria de dicho país a evaluar y verificar saldos o pérdidas de períodos prescritos.

Así, el artículo 52 del Reglamento de la Ley del Procedimiento Fiscal (Decreto Reglamentario de la Ley $\mathrm{N}^{\circ}$ 11683) establece expresamente: "Pueden verificarse los quebrantos impositivos correspondientes a años prescriptos cuando inciden en determinaciones exigibles."

Esta norma se complementa con lo señalado en el artículo 48 del mismo reglamento:

Los contribuyentes o responsables deberán conservar los comprobantes y documentos que acrediten las operaciones vinculadas a la materia imponible, por un término que se extenderá hasta 5 (cinco) años después de operada la prescripción del periodos fiscal a que se refieran.

A diferencia del caso peruano, en Argentina existe una norma que permitiría a la Administración a efectuar modificaciones en los arrastres de saldos o pérdidas de períodos prescritos a efectos de proyectarlos hacia períodos no prescritos y que son sujetos de fiscalización tributaria.

Sin embargo, resulta importante destacar que las citadas normas argentinas se encuentran en un reglamento y por ello han sido objeto de una acción de inconstitucionalidad que aún no cuenta con un pronunciamiento definitivo. 
La referida acción de inconstitucionalidad ha sido motivada por ir contra del principio de seguridad jurídica, el cual, como hemos desarrollado a lo largo de la presente investigación, es uno de los componentes esenciales de la prescripción. A nivel de doctrina, podemos mencionar que Navarrine (2012) opina lo siguiente sobre las normas en mención:

El quebranto (renta negativa) integra la obligación tributaria y es condicionante para el cálculo del monto imponible. Si la obligación tributaria está prescripta, el quebranto como componente de ella - también se rige por ese límite temporal (...) Por todo ello, la naturaleza jurídica del quebranto impide el ejercicio de las facultades del Fisco para ajustarlo, las que no son imprescriptibles, por obra del art. 52 del reglamento de la ley 11.683. El error de la jurisprudencia que admitió el ajuste del quebranto de la obligación prescripta debe subsanarse, y tener en cuenta la solución comentada, para lograr una jurisprudencia acorde con la ley 11.683. (p. 10) (el resaltado es nuestro).

Finalmente, también llama la atención la posición adoptada por el Tribunal Fiscal argentino y por el Reglamento de la Ley $\mathrm{N}^{\circ} 11683$ cuando el artículo 118 de ésta señala que "hasta que la Administración Federal de Ingresos Públicos proceda a impugnar las declaraciones juradas mencionadas en el artículo 117 y practique la determinación prevista en el artículo 17 y siguientes, se presumirán, sin admitir prueba en contrario, la exactitud de las declaraciones juradas presentadas por el resto de los períodos anteriores no prescriptos". Así, en el caso argentino tenemos una norma iure et de iure que valida las declaraciones presentada por los contribuyentes y las presume correctas.

Nótese que la norma antes citada hace expresa referencia a las declaraciones juradas de períodos no prescritos porque considera que éstas pueden ser modificadas mediante la fiscalización que pueda efectuar la Administración Tributaria pues aún mantiene esa facultad. En el caso de declaraciones juradas de períodos prescritos, consideramos que no era necesaria esta referencia debido a que no existe norma legal alguna que permita la modificación de la declaración jurada de períodos prescritos ya que la potestad de la administración ya no puede ejercerse. Con ello, consideramos que la interpretación del Tribunal Fiscal argentino no es correcta y no tiene asidero legal pues valida la modificación de la determinación de períodos prescritos, tal como pretende realizar el Tribunal Fiscal peruano. 
Adicionalmente, la Corte Suprema de Justicia de Chile se ha pronunciado recientemente de la revisión que puede realizar la Administración Tributaria de períodos prescritos, aunque en nuestra opinión, limitándola a la cuantía, más no a la posibilidad de modificarla o desconocerla al determinar la obligación del período no prescrito. Así, en la sentencia de fecha 16 de junio de $2014^{27}$, señaló lo siguiente:

Que en lo concerniente al conflicto jurídico en que radica la protesta del impugnante, ésta ha sido planteado, debatido y decidido en reiteradas ocasiones por esta Corte, asentándose una doctrina clara al respecto, por lo cual, tratándose de la determinación de un impuesto actual en que el contribuyente hace valer pérdidas de arrastre provenientes de ejercicios anteriores al amparo del artículo 31 de la Ley del Impuesto a la Renta, tal como el caso de estos antecedentes, el Servicio de Impuestos Internos, al exigir que se acrediten fehacientemente tales pérdidas no está ejerciendo sus facultades fiscalizadoras para revisar impuestos prescritos, sino sólo controlando que los gastos que se hacen valer respecto de la determinación de un impuesto actual se encuentren justificados.

Este tema también ha sido analizado en España aunque con criterios disímiles y no uniformes. Al respecto, revisaremos el caso específico seguido contra el contribuyente Beam Global España ${ }^{28}$, en el que la Audiencia Nacional (que sería el equivalente al Tribunal Fiscal peruano), adopta una posición distinta a la del Tribunal Económico Administrativo Central (en adelante, TEAC y que sería el equivalente a SUNAT).

En este caso, el TEAC realizó una acotación al contribuyente, modificando las "bases imponibles negativas" (equivalentes a las pérdidas tributarias) de un período que ya se encuentra prescrito, que fueron compensadas en ejercicios siguientes y que son materia de revisión tributaria (aún no prescritos).

Al respecto, la Audiencia Nacional española, en sus considerandos señala:

$\mathrm{Si}$, efectivamente, las facultades de comprobación pudieran soslayar el plazo de prescripción, se colocaría a la Administración en una clara situación de privilegio respecto

27 Expediente 10817-2014 de la Corte Suprema de Justicia de Chile.

28 El expediente ante la Audiencia Nacional fue signado con el $\mathrm{N}^{\circ}$ 249/2009 y la resolución fue emitida el 24 de mayo de 2012. Posteriormente, el Tribunal Supremo revisó el caso (Expediente $\mathrm{N}^{\circ}$ 2883/2012) y emitió su fallo el 9 de diciembre de 2013. 
del contribuyente. La Inspección podría, en efecto, comprobar la legalidad de una operación, dato o declaración más allá del plazo prescriptorio (concretamente hasta que transcurra el lapso temporal en el que puede efectuarse la compensación); el sujeto pasivo, sin embargo, no estaría habilitado para corregir los errores detectados en las declaraciones correspondientes a ejercicios prescritos, aunque dichos errores pudieran proyectarse a los créditos compensables en el futuro.

En resumen, la Sala entiende que la cantidad consignada como base imponible negativa en el ejercicio 99/00 (derivado de la dotación a la provisión por depreciación de cartera efectuada por PEDRO DOMECQ S.A.) ha adquirido firmeza, en virtud de la prescripción, por lo que no cabe su modificación (...). La cantidad compensada por el contribuyente en el ejercicio 2000/2001, procedente de la base imponible negativa del ejercicio 1999/2000 debe estimarse, por los tanto, correcta, sin que quepa alteración de la misma por parte de la Inspección.

Como se puede apreciar, el criterio adoptado por la Audiencia Nacional española, es que no es posible modificar la determinación de un ejercicio prescrito, en la medida que por efecto de la prescripción, la declaración o determinación efectuada por el contribuyente constituye un acto firme e inmodificable.

No obstante, cuando el caso fue revisado por el Tribunal Supremo se desestimó la posición adoptada por la Audiencia Nacional española, principalmente por la incorporación de un apartado en la Ley 40/1998 que modificó la Ley del Impuesto sobre Sociedades, que indicaba:

El sujeto pasivo deberá acreditar, en su caso, mediante la exhibición de la contabilidad y los oportunos soportes documentales, la procedencia y cuantía de las bases imponibles negativas cuya compensación pretenda, cualquiera que sea el ejercicio en el que se originaron.

Así, en aplicación de esta norma, el Tribunal Supremo sostiene que al hacerse referencia a la expresión "cualquiera que sea el ejercicio en el que se originaron", incluye a los períodos prescritos. Nótese que los contribuyentes en estos casos deben demostrar la procedencia y cuantía, pero ¿sería posible que la Administración Tributaria revise los hechos de los 
períodos prescritos para modificar esta determinación? A criterio del mencionado tribunal, esto no sería posible.

Como puede apreciarse en la Sentencia del Tribunal Supremo sobre este caso ${ }^{29}$ (de fecha 9 de diciembre de 2013), expresamente se indicó:

(...) lo que llevó a cabo la Administración fue una recalificación fiscal de un conjunto o entramado negocial ocurrido en el período impositivo 1999/2000, ya prescrito, cuyos efectos y alcance tributario se proyectaron directamente en el posterior 2000/2001, mediante el arrastre y compensación de las bases imponibles generadas en el anterior.

$(\ldots)$

En suma, como las operaciones descritas, aisladamente consideradas, eran válidas y ajustadas a derecho, si bien, apreciadas en su conjunto, buscaban y provocaban una menor tributación de manera artificiosa, se trataba de un supuesto de conflicto en la calificación de la norma o de fraude de ley, para cuya constatación resultaba necesario investigar sobre la forma en que se contabilizaron las operaciones y se realizaron los ajustes extracontables por las diferentes sociedades del grupo, y más en concreto por JHE, en un ejercicio para el que había prescrito ya el derecho de la Administración a hacerlo" (el subrayado es nuestro).

Así, el Tribunal Supremo español reconoce que la Administración Tributaria puede solicitar información de períodos prescritos para determinar que la cuantía del saldo incorporado en la declaración del período no prescrito, es igual al importe declarado y contabilizado en el período que se originen aunque éste se encuentra prescrito. De ningún modo, se valida que pueda efectuarse una nueva revisión para modificar esa cuantía, incluso cuando en el caso concreto, existían claros indicios de una defraudación tributaria.

En este orden de ideas, la norma incorporada en la Ley de Sociedades española, resulta de aplicación para la solicitud de información de períodos prescritos. Así, si trasladamos este criterio a un caso peruano, podríamos indicar que la Administración Tributaria podría solicitar información relativa a un período prescrito para comprobar que

29 Ver Sentencia de la Sala de lo Contencioso del Tribunal Supremo de España mencionada en la nota anterior. 
el saldo a favor o pérdida tributaria consignada en la declaración de un período no prescrito, es el mismo y no tiene diferencias.

Para ello, en nuestra opinión, bastaría con que el contribuyente exhiba la declaración jurada correspondiente al período prescrito (que como sabemos ya tiene un carácter invariable e inmodificable) en el que se consignó el importe que forma parte de la declaración del período no prescrito sujeto a fiscalización.

También resulta importante señalar que en el caso español, en el año 2003, se realizó una modificación de la Ley General Tributaria mediante la cual se introdujeron algunas consideraciones vinculadas con este tema.

En primer lugar, en el Artículo 70.3 de la Ley General Tributaria española se indica lo siguiente:

La obligación de justificar la procedencia de los datos que tengan su origen en operaciones realizadas en períodos impositivos prescritos se mantendrá durante el plazo de prescripción del derecho para determinar las deudas tributarias afectadas por las operaciones correspondientes.

En este caso, consideramos que, tal como se señaló anteriormente al comentar la norma de la Ley de Sociedades de España, bastará con que el contribuyente demuestre el origen del importe que es incorporado en la liquidación de un período no prescrito, pero de ninguna manera permite la modificación de la determinación efectuada por el contribuyente en el caso de los ejercicios prescritos.

La otra incorporación realizada en la Ley General Tributaria española la encontramos en el Artículo 106.4 que indica expresamente, refiriéndose a las bases imponibles negativas que tengan su origen en ejercicios prescritos: "La procedencia y cuantía de las mismas deberá acreditarse mediante la exhibición de las liquidaciones o autoliquidaciones en que se incluyeron la contabilidad y los oportunos soportes documentales". 
Este texto, a nuestra consideración, reafirma que la Administración Tributaria no puede modificar la determinación de períodos prescritos para llevar sus efectos a períodos no prescritos; lo único que permite hacer es revisar si efectivamente los importes incorporados corresponden a lo que el contribuyente declaró en su oportunidad, sin poder cuestionar si estuvo bien determinado o no, producto del efecto de la prescripción.

En este mismo sentido se pronuncia García Novoa (2011b), con quien compartimos el siguiente criterio:

(...) la firmeza de la base o cuota negativa determina la imposibilidad de comprobar el período prescrito en que se generó la base imponible negativa. Pero el deber de acreditar las bases negativas y de hacerlo mediante la exhibición de las declaraciones y autoliquidaciones y los oportunos soportes documentales, incluye la posibilidad de constatar la realidad y la existencia de la base o cuota negativa, sin poder alterar su cuantía, pues ello sería incompatible con su condición de prescrita. En suma, lo que se podrá es comprobar la obligación tributaria no prescrita a la que se incorpora la base negativa de otro período prescrito. Para ello se podrá verificar la producción de esa base, pero no rehabilitar la comprobación de unas facultades prescritas. (p. 51) (el subrayado es nuestro).

En el mismo trabajo antes citado, García Novoa concluye que la Administración solo debe verificar el importe que haya sido declarado:

En suma, y en tanto la LGT limita los medios de acreditación a la exhibición de declaraciones y autoliquidaciones y de sus oportunos soportes, la función comprobadora de la Inspección respecto de saldos compensados en períodos no prescritos que se generaron en períodos prescritos, se limitará a la mera verificación de que la base se ha declarado en el Impuesto sobre Sociedades o el saldo haya sido declarado en la correspondiente autoliquidación del IVA, sin que pueda entrar a analizar la composición o procedencia de dicha base o saldo. (p. 56) (el subrayado es nuestro).

Como podemos apreciar, lo que se permite a la Administración Tributaria es constatar que el saldo a favor o crédito, sea real, no existiendo la posibilidad de modificar su cuantía pues al provenir de un ejercicio prescrito, dicho crédito es inmodificable. 
Incluso, podría discutirse si los encargados de la revisión podrían solicitar la información antes referida pues las declaraciones efectuadas por los contribuyentes se encuentran en poder de la Administración Tributaria y, en sentido estricto, bastaría que ella compruebe en sus registros la cuantía y existencia del crédito declarado, sin posibilidad de modificación.

\subsubsection{Segundo caso: modificación de la determinación de un período prescrito para proyectar sus efectos a uno no prescrito en el caso del Impuesto General a las Ventas.-}

En el caso del Impuesto General a las Ventas, debemos recordar que por la dinámica de este impuesto, pueden existir saldos a favor que son arrastrados a ejercicios siguientes a efectos de ser compensados (crédito fiscal).

Al respecto, en un caso específico vinculado con este impuesto, el Tribunal Fiscal valida un arrastre de saldo a favor de períodos prescritos; la Resolución N 1409-4-2013, señala:

Que en cuanto a la supuesta imposibilidad de efectuar el arrastre del saldo a favor del Impuesto General a las Ventas de enero a noviembre de 1998, es pertinente señalar que este Tribunal en reiterada jurisprudencia, tales como las Resoluciones $\mathrm{N}^{\circ} 100-5-2004,322-1$ 2004 y 02838-5-2010, ha establecido que la Administración puede revisar períodos prescritos, no con la finalidad de determinar la deuda de dichos períodos sino a fin de derivar consecuencias tributarias para períodos no prescritos susceptibles de ser fiscalizados, por lo que carece de sustento lo alegado por la recurrente al respecto.

En el mismo sentido se pronuncia la Resolución del Tribunal Fiscal No 2921-1-2004 en la que incluso se valida la revisión de períodos prescritos:

Que la Administración no puede dejar de tener en cuenta el crédito fiscal por adquisiciones anteriores a diciembre de 1996, con el argumento que son períodos prescritos, toda vez que de conformidad con el criterio establecido en la Resolución del Tribunal Fiscal No. 100-52004 del 9 de enero de 2004, el cómputo de la prescripción debe efectuarse en función de la obligación tributaria que se pretende determinar y/o cobrar y no en función de los hechos, como podrían ser las mencionadas adquisiciones que pudieran incidir en la determinación. 
Que ello se debe, como se refiere en la citada resolución, a que el transcurso del tiempo que se traduce en la prescripción tiene la finalidad de otorgar a los deudores tributarios un medio de defensa contra una actuación o pretensión de la Administración Tributaria $(\ldots)$

Que en este orden de ideas, la Administración deberá proceder a verificar si el saldo del Impuesto General a las Ventas de períodos anteriores a diciembre de 1998, cumple con los requisitos para ser admitido como crédito fiscal, a fin de aplicarlo contra el monto del débito establecido en la Resolución de Determinación (...) y de ser el caso imputarlo contra los períodos posteriores, procediendo a la reliquidación de los montos girados" (el subrayado es nuestro).

También podemos mencionar la Resolución del Tribunal Fiscal N 7545-2-2004, en la que se resalta el criterio seguido en la resolución citada anteriormente y en la Resolución $\mathrm{N}^{\circ}$ 100-5-2004:

Que en ese sentido, considerando que la mencionada resolución [100-5-2004] concluyó que a la facultad de fiscalizar le resultan aplicables los plazos previstos para las deudas tributarias de los períodos que está determinando, el plazo de prescripción a considerarse en el caso de autos sería el aplicable al Impuesto General a las Ventas de octubre de 1996

Que en el mismo sentido, la Resolución del Tribunal Fiscal No. 2921-1-2004, basándose en la Resolución No. 100-5-2004, concluyó que no se puede dejar de tener en cuenta el crédito fiscal por adquisiciones anteriores al período tributario cuya obligación tributaria se pretende determinar y/o cobrar, con el argumento que el crédito fiscal por adquisiciones anteriores corresponden a períodos prescritos.

Finalmente, podemos mencionar la Resolución del Tribunal Fiscal № 09156-1-2004 que señala lo siguiente:

Que respecto al argumento de la recurrente en el sentido que la Administración no podía determinar el saldo a favor de junio a octubre de 1994 por tratarse de obligaciones prescritas, cabe indicar que conforme lo ha establecido este Tribunal en la Resolución $\mathrm{N}^{\circ}$ 100-5-2004, la facultad de fiscalización estará sujeta a los plazos del Artículo 43 del Código Tributario en función de la obligación tributaria que, a través de ella, se pretende determinar (y cobrar), con prescindencia de si los hechos y situaciones que están siendo 
fiscalizados por incidir en la determinación de dicha obligación se produjeron en un período distinto al que ésta corresponde, lo que se pone de manifiesto por el hecho que los plazos de prescripción que establece el Código Tributario toman como punto de referencia el nacimiento y la exigibilidad de la obligación tributaria, haciendo explícita la vinculación entre la facultad de fiscalización y el tributo y período materia de determinación (y cobro) y dado que en el presente caso se determinó el saldo a favor del Impuesto General a las Ventas de los meses de marzo de 2001 a febrero de 2002 tomando en cuenta el arrastre del crédito fiscal desde junio de 1994, cuando aun no había prescrito la facultad de la Administración respecto de dichos períodos, carece de sustento lo alegado por la recurrente.

Es evidente que lo que realiza el Tribunal Fiscal en las resoluciones antes mencionadas es que los saldos a favor del Impuesto General a las Ventas de períodos prescritos pueden ser "nuevamente determinados" para efectuar el arrastre a períodos no prescritos pues lo que importa para el cómputo de la prescripción, es el mes referido al cálculo de la obligación, más no aquél que tenga incidencia.

Cabe precisar además, que no consideramos correcta la referencia que se realiza a la Resolución del Tribunal Fiscal N 100-5-2004 pues en ésta se discutía si era posible revisar operaciones vinculadas con el ejercicio no prescrito en revisión. En el caso de las Resoluciones vinculadas con el Impuesto General a las Ventas, lo que hace el Tribunal Fiscal es resolver la controversia en el sentido si una autodeterminación ya devenida en firme (por tratarse de un período prescrito) y que ha sido incorporada a una determinación de ejercicios no prescritos puede ser modificada.

No coincidimos con el criterio expuesto por el Tribunal Fiscal pues en nuestra opinión, como ya lo hemos señalado a lo largo de la presente investigación, modificar la determinación de un período prescrito para validar las determinaciones de períodos sujetos a fiscalización, constituye una nueva fiscalización y una nueva determinación que solo puede ser efectuada si el período no se encuentra prescrito y mediante la emisión de una Resolución de Determinación. Así, resulta claro que el Tribunal pretende validar quer los saldos del Impuesto General a las Ventas que no fueron fiscalizados oportunamente pueden ser nuevamente revisados si es que se arrastran a períodos tributarios que no han sido 
fiscalizados y por los cuales aún se encuentra vigente la facultad de determinación por parte de la Administración Tributaria.

\subsubsection{Tercer caso: arrastre de pérdidas y saldos a favor.-}

Si bien hemos revisado hasta aquí la posibilidad que la Administración Tributaria verifique un ejercicio prescrito para proyectar sus efectos a períodos no prescritos, también es importante revisar qué pasaría si es que el ejercicio prescrito se encuentra entre dos ejercicios que aún se encuentran en fiscalización. Esta situación podríamos graficarla de la siguiente manera:

Figura 2.1.

Ejercicio prescrito entre dos ejercicios que aún se encuentran en fiscalización

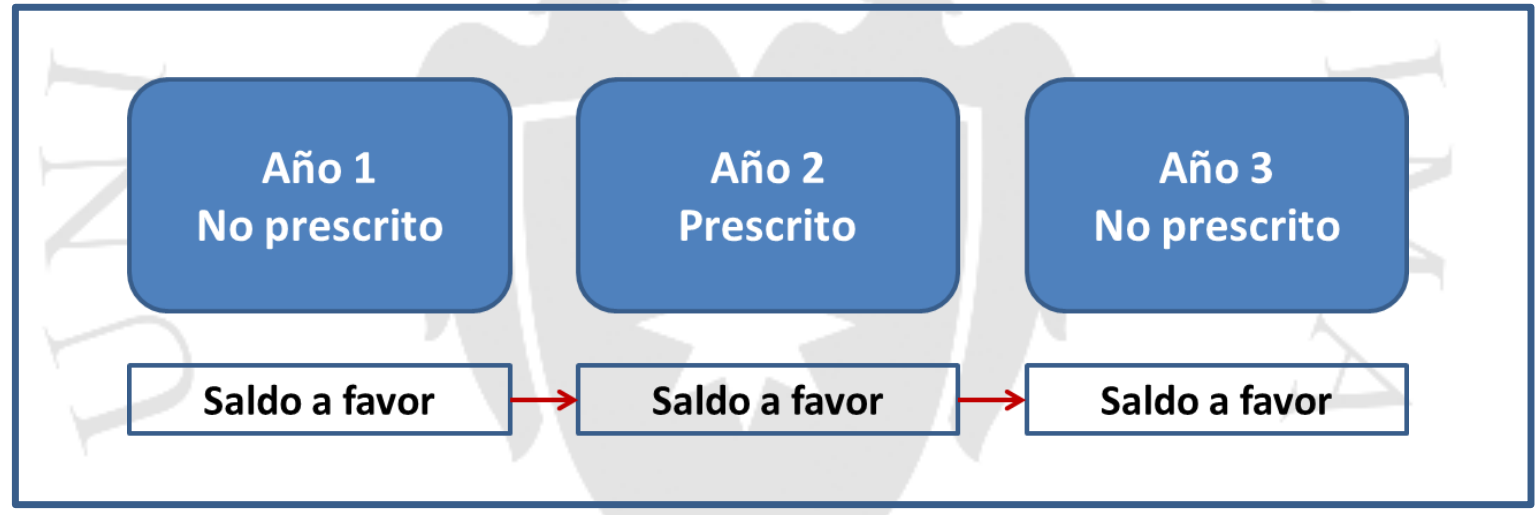

En este escenario, ¿podría la Administración Tributaria, en función de la modificación de la determinación del "Año 1", proyectar los efectos al "Año 2" y, a su vez, al "Año 3"? Recordemos que por lo estudiado hasta aquí, la única manera mediante la cual la Administración puede modificar la determinación de un ejercicio es con la emisión del acto administrativo correspondiente, es decir, una Resolución de Determinación.

Así, si bien la Administración podrá emitir una Resolución de Determinación por el “Año 1", disminuyendo el saldo a favor, consideramos que no sería posible que ese efecto sea llevado al "Año 2" a efectos de disminuir el saldo a favor declarado por el contribuyente (recordemos que no se emitirá una Resolución de Determinación por este 
período por encontrarse prescrito) y proyectar dicha disminución al "Año 3” (por el que sí se podría emitir otra Resolución de Determinación).

Al respecto, podemos mencionar que el Tribunal Fiscal ha adoptado un criterio en el sentido que sí es posible que la Administración Tributaria efectúe una reliquidación de las pérdidas tributarias arrastrables, a pesar que se encuentren vinculadas con ejercicios prescritos. Así, por ejemplo, podemos mencionar la Resolución del Tribunal Fiscal $N^{\circ}$ 17618-1-2012, en la que se señala lo siguiente:

(...) operada la prescripción, la Administración no podrá determinar y/o exigir el pago de la obligación tributaria prescrita, sin embargo, ello no impediría el arrastre de pérdidas por períodos prescritos; a efectos de determinar la obligación tributaria de un período distinto; toda vez que, dicho arrastre, no implica la determinación de obligación tributaria o exigencia del pago respecto del o los períodos prescritos; sino únicamente el arrastre de una pérdida para la determinación de la obligación tributaria de un período distinto y no prescrito.

En el mismo sentido se pronuncia la Resolución del Tribunal Fiscal N 6638-9-2012:

(...) la Administración debía cumplir con actualizar el saldo a favor de ejercicios anterior y los pagos a cuenta del ejercicio 2001 compensados, a efecto de reliquidar el Impuesto a la Renta del ejercicio 2001 y emitir nuevo pronunciamiento al respecto (...) para lo cual era necesario que la Administración verificara el arrastre y compensación de los saldos a favor de los períodos anteriores a partir de sus declaraciones juradas, como en efecto lo hizo, no pudiéndose alegar que tal verificación de saldos (ejercicios 1998, 1999 y 2000) corresponde a una fiscalización, como pretende sostener la recurrente.

Así mismo, una reciente resolución del Tribunal Fiscal confirmaría el criterio adoptado por este órgano colegiado. En la Resolución N 02569-11-2015, se ha señalado lo siguiente sobre la posibilidad de arrastrar consecuencias de períodos prescritos a ejercicios no prescritos:

Que sin perjuicio de lo expuesto, debe precisarse que la prescripción de la acción para determinar y exigir el pago del Impuesto a la Renta del ejercicio 1999 solo está referido a la imposibilidad de la Administración de ejercer la acción de determinación de la obligación tributaria de dicho ejercicio, así como su materialización mediante el acto administrativo 
idóneo, como sería una resolución de determinación, y el ejercicio de acciones de cobranza de la deuda determinada por eseejercicio respecto del cual se ha declarado la prescripción, lo que no ha ocurrido en el caso materia de autos por cuanto la prescripción declarada sobre un período específico no implica desconocer aquellos aspectos que guarden relación con la obligación tributaria y su manifiesta incidencia o efectos en otros períodos respecto de los cuales no se ha declarado la prescripción, ello debido a la continuidad propia de las obligaciones tributarias y al establecimiento de periodocidad solo para efectos de regular su nacimiento, determinación y/o liquidación.

Que en tal sentido, la declaración de prescripción del Impuesto a la Renta del ejercicio 1999 no impide reconocer la incidencia o efectos de aquellos aspectos vinculados a dicho ejercicio u otros a fin de determinar la obligación tributaria de un período respecto del cual no se ha declarado la prescripción, esto es, considerar el arrastre del saldo a favor del ejercicio 1998 determinado en forma definitiva en sede administrativa (...) a los ejercicios siguientes y como consecuencia de ello variar el cálculo del saldo a favor del ejercicio 1999 a ser aplicado para los pagos a cuenta del ejercicio 2000, tal como lo ha establecido este Tribunal en la Resolución N 17618-1-2012 al afirmar que se encontraba conforme a ley las consecuencias derivadas respecto del período prescrito por el arrastre de pérdidas del Impuesto a la Renta a períodos distintos y no prescritos" (el subrayado es nuestro).

En la resolución antes mencionada se incluyen diversos aspectos que hemos analizado a lo largo de esta investigación y con los que definitivamente no concordamos pues, en nuestra opinión, desnaturalizan los efectos de la prescripción y las formalidades que deben cumplirse para la determinación de la obligación tributaria.

Así, por ejemplo, el Tribunal Fiscal señala que la declaración de prescripción implica que no podrá efectuarse la determinación del ejercicio prescrito mediante el acto administrativo idóneo ni el ejercicio de acciones de cobro, sin embargo, sí valida que la determinación sea de un período prescrito sea modificada a efectos de arrastrar los nuevos importes a períodos no prescritos. Cabe preguntarnos entonces, ¿modificar importes declarados por los contribuyentes no implica efectuar una determinación? 
Al respecto, el propio Tribunal Fiscal, en el segundo párrafo citado de la Resolución $\mathrm{N}^{\circ}$ 02569-11-2015 reconoce que el arrastre de saldos a favor de períodos prescritos a ejercicios no prescritos, constituye una variación de la declaración jurada del contribuyente. Esta modificación, como lo hemos desarrollado anteriormente, solo puede ser efectuada por un acto administrativo idóneo, es decir, una resolución de determinación pues constituye una variación de la obligación tributaria.

En este escenario, resulta de vital importancia considerar qué se entiende por obligación tributaria. Como ya hemos revisado en el acápite 2 del Capítulo I de la presente investigación, nuestra opinión es que la obligación tributaria incluye a los saldos a favor y a las pérdidas arrastrables por lo que discrepamos con lo expuesto por el Tribunal Fiscal en las resoluciones citadas.

En estricto y para efectos prácticos, siguiendo con el análisis de la situación de arrastre de saldos, es verdad que en el "Año 2" (producto de la fiscalización del "Año 1") existe un menor saldo a favor del contribuyente pero lo que no puede negarse es que producto de la inacción de la Administración Tributaria el contribuyente no puede verse perjudicado.

Como lo hemos señalado en esta investigación, la declaración jurada del contribuyente es el acto formal mediante el cual se determina la obligación tributaria (sea tributo por pagar o saldo a favor) por lo que necesariamente debe ser modificado por otro acto formal, como lo es una Resolución de Determinación, pero únicamente por los ejercicios en los que la Administración se encuentre facultada a hacerlo. En el ejemplo propuesto, ello ya no es posible de efectuar en el denominado "Año 2" por lo que el importe declarado por el contribuyente resulta firme e inmodificable.

Cabe precisar que lo declarado por el contribuyente, al tener carácter de declaración jurada, es su mejor determinación en función de la información con la que contaba al momento de calcular su obligación tributaria; ello, al margen de la interpretación que pueda tener la Administración Tributaria sobre la misma. 
A lo que queremos llegar con ello es que no necesariamente el contribuyente ha buscado un beneficio o provecho al declarar un saldo superior al que le correspondía pues esta disminución es producto de la revisión y los criterios de la Administración Tributaria.

Ahora bien, aunque resulte discutible, en el caso resuelto por el Tribunal Supremo español, que revisamos anteriormente ${ }^{30}$, incluso existían indicios de una defraudación pero no validó la modificación de la declaración del contribuyente que pretendía realizar la Administración Tributaria, al tratarse de un ejercicio prescrito y por el que ya no era posible efectuar una nueva revisión. En este caso el Tribunal hizo prevalecer el principio de seguridad jurídica frente a la facultad de fiscalización y determinación.

Así, en el ejemplo planteado, y al margen de la intención que haya tenido el contribuyente $^{31}$ al efectuar la declaración jurada del "Año 2" (evidentemente asumiremos la buena fe del contribuyente y que no tuvo intención alguna de evadir o defraudar), lo consignado en su declaración jurada debe ser respetado y mantenerse invariable para determinar la obligación tributaria del "Año 3", en estricto cumplimiento de los principios que subyacen a la prescripción y sus efectos en los ejercicios posteriores. Así, la Administración Tributaria solo podrá fiscalizar y, por ende, determinar, el "Año 1" y el "Año 3", considerando en este último los importes declarados como saldo a favor o créditos por el contribuyente en el "Año 2".

Esta posición se sustenta, además, en la Resolución del Tribunal Fiscal № 2282-32014, en la que se ha indicado lo siguiente:

Que al respecto, debe tenerse en consideración que en la Resolución N$^{\circ}$ 01322-1-2004, este Tribunal señaló que la Administración no se encontraba facultada a iniciar la fiscalización, y en consecuencia, a modificar la determinación realizada por la recurrente respecto a los meses de enero a setiembre de 1997, y que no se emitió valor alguno que modifique la determinación del débito fiscal en los meses octubre y noviembre de 1997, por lo que

30 Nos referimos al caso señalado en la Nota 28.

31 No desconocemos que, en caso se demuestre algún tipo de defraudación se sigan las acciones que permitan, de ser el caso, castigar dicha conducta (por ejemplo, alguna acción penal, en la medida que no haya prescrito la facultad para iniciarla). 
corresponde revocar la apelada en dicho extremo, debiendo la Administración considerar el $\underline{\text { saldo a favor consignado por la recurrente en la declaración jurada correspondiente a }}$ diciembre de 1997, redeterminando la obligación tributaria de dicho período así como las correspondientes a enero y febrero de 1998, de ser el caso. (el subrayado es nuestro)

En el mismo sentido se pronunció el Tribunal Fiscal en la Resolución $N^{\circ}$ 1973-8-2012, en la que se señala lo siguiente respecto de la determinación del Impuesto a la Renta del ejercicio 2000 de un contribuyente:

Atendiendo a lo señalado y considerando que la procedencia del saldo a favor se encontraba directamente relacionada con lo que se resolviera en los Expedientes $\mathrm{N}^{\circ}$ 97042005 y N ${ }^{\circ} 1248-2008$ antes citados, en los que se determinaría el importe del Impuesto a la Renta correspondiente a los ejercicios gravables 1998 y 1999, ordenó a la Administración que estuviera a la resuelta de lo que se estableciera en el procedimiento contencioso tributario iniciado en el expediente $\mathrm{N}^{\circ}$ 9704-2005 a efecto de determinar la procedencia en la aplicación de este importe.

En el caso del Impuesto a la Renta del ejercicio 1998 (Expediente $N^{\circ}$ 9704-2005), este Tribunal resolvió el recurso de apelación interpuesto, mediante la Resolución $\mathrm{N}^{\circ}$ 11450-5-2011 de 5 de julio de 2011, y cuya resolución de cumplimiento ha sido resuelta mediante la Resolución $N^{\circ}$ 00974-5-2012 de este Tribunal por lo que en cumplimiento de lo dispuesto en la Resolución no correspondía que la Administración considerase un saldo a favor de ejercicios anteriores, respecto de los cuales aún no existía un pronunciamiento final en sede administrativa.

De otro lado, para el caso del Impuesto a la Renta del ejercicio 1999, en las Resoluciones $\mathrm{N}^{\circ} 14771-3-2010$ y N 16603-4-2010 se declaró la nulidad de los valores emitidos por anticipos y por el pago de regularización de dicho tributo y período; motivo por el cual -salvo que se practique una nueva determinación de oficio- la Administración debe tomar en consideración los importes declarados por la recurrente. (El subrayado es nuestro)

Como puede apreciarse, el Tribunal Fiscal reconocería que, ante la imposibilidad de efectuar una nueva determinación por haber operado la prescripción, el saldo a favor (o crédito, de ser el caso) que debe ser utilizado para la determinación de la obligación 
tributaria del período sujeto a fiscalización, es el declarado por el contribuyente, no existiendo como alternativa, la modificación de la obligación tributaria.

No obstante, al parecer este criterio no sería el predominante al momento de resolver, optándose más bien, porque una modificación de períodos prescritos es posible sin necesidad de emitir una resolución de determinación.

\subsection{Nuestra propuesta.-}

Como hemos podido revisar a lo largo del presente capítulo, tanto SUNAT como el Tribunal Fiscal han adoptado diversas posturas sobre los efectos que produce la prescripción en la facultad de fiscalización y determinación de la obligación tributaria.

Así, se ha reconocido que la Administración Tributaria puede solicitar información de períodos en los que ya operó la prescripción en la medida que tenga incidencia en la determinación de períodos no prescritos e incluso, siguiendo algunas resoluciones del Tribunal Fiscal, modificar la determinación de los períodos prescritos para proyectar sus efectos y consecuencias a los períodos que aún son materia de revisión por parte de la Administración.

En nuestra opinión, de acuerdo con lo señalado por el Código Tributario, el propio Tribunal Fiscal y por los principios reconocidos por el Poder Judicial y el Tribunal Constitucional, la prescripción constituye, sin duda alguna, un límite temporal a la facultad de fiscalización y determinación de la Administración Tributaria. En ese sentido, el hecho de solicitar información o modificar la determinación de períodos prescritos, transgrede el derecho a la seguridad jurídica de los contribuyentes.

Como revisamos en este capítulo, hace algunos años el Grupo Peruano de la IFA, efectuó una recomendación en el sentido que la Administración Tributaria debería encontrarse impedida de efectuar reparos o modificaciones sobre ejercicios que ya fiscalizó para proyectar los efectos a períodos no prescritos. Sin embargo, consideramos que esta recomendación debió ser más amplia y no limitarse a los períodos que ya han sido fiscalizados, sino también a aquellos por los que la Administración Tributaria se encuentra 
impedida de revisar la determinación de la obligación tributaria por efectos de la prescripción.

Así mismo, como hemos analizado en esta investigación y en aplicación de las normas vigentes sobre la materia, la obligación tributaria puede ser modificada únicamente mediante la emisión de un documento idóneo para ello, esto es, una Resolución de Determinación; resulta claro inferir que la mencionada resolución solio podrá emitirse respecto de períodos en los que la facultad de fiscalización y determinación de la Administración Tributaria aún no ha prescrito.

Como propuesta, y reconociendo que la seguridad jurídica es la que debe prevalecer ante estas situaciones, consideramos que debería modificarse el Código Tributario a efectos que se precise que la Administración Tributaria únicamente podrá solicitar información vinculada con ejercicios que no se encuentren prescritos al margen si fueron fiscalizados o no o si tienen incidencia en períodos prescritos.

Además, debería incorporarse la posibilidad de destruir los documentos una vez que se haya obtenido la resolución que reconozca la prescripción del ejercicio, tal como se permite en otros países.

Ello, también sería aplicable para los casos de cruces de información y solicitud de documentación a terceros para verificar el cumplimiento de las obligaciones tributarias pues es común que la Administración Tributaria efectúe este tipo de requerimientos sobre períodos anteriores, pudiendo generarse que el contribuyente fiscalizado tenga el ejercicio abierto pero el contribuyente (tercero) a quien le solicitan información tenga el mismo ejercicio prescrito.

Esta propuesta, evidentemente, no solo se limitaría a la posibilidad de solicitar información de períodos prescritos, sino también a que la Administración Tributaria se encuentre impedida de modificar la determinación de la obligación de estos períodos, al margen si tienen incidencia en ejercicios abiertos a fiscalización.

Con ello también se generaría un incentivo para que la Administración Tributaria cumpla con los plazos para efectuar las revisiones y, en caso no se efectúe la fiscalización, 
la determinación de la obligación tributaria realizada por los contribuyentes obtenga el carácter de definitivo e inmodificable producto del paso del tiempo sin que se hayan ejercido las acciones fiscalizadoras.

Cabe precisar que actualmente, si bien las fiscalizaciones tienen un plazo fijado para su conclusión, considerando las interrupciones o suspensiones del plazo de prescripción, muchas veces se determina la obligación tributaria de los ejercicios gravables luego de 8 o 10 años, generando una incertidumbre que no ayuda a los contribuyentes ni a la Administración Tributaria.

Otra alternativa, que también implicaría una modificación al Código Tributario sería incorporar una norma similar a la contenida en la legislación española en el sentido que únicamente se podría solicitar información vinculada con períodos prescritos que permita acreditar las cifras consignadas en las declaraciones juradas, es decir, una revisión cuantitativa destinada a acreditar el origen de los saldos consignados por los contribuyentes.

Así, por ejemplo, bastaría con exhibir la información contable o las declaraciones juradas presentadas en ejercicios anteriores a efectos de acreditar el correcto arrastre de saldos a favor, pérdidas, depreciaciones, entre otros. Como se analizó en la presente investigación, no tendría sentido que la Administración Tributaria solicite información vinculada con el origen de activos que se siguen depreciando por 20 o 30 años; bastaría, en nuestra opinión, con presentar la información contable que acredite que la depreciación consignada en períodos fiscalizados y que tiene su origen en períodos que ya se encuentran prescritos es la correcta. 


\section{CONCLUSIONES}

- La facultad de fiscalización y determinación con la que cuenta la Administración Tributaria se basa en la potestad que le otorga la Constitución; sin embargo, esta facultad no puede ser ejercida de manera irrestricta o ilimitada. Así, entre los límites aplicables, encontramos el respeto a los derechos fundamentales de los contribuyentes, la aplicación y cumplimiento de los principios contemplados en la Ley del Procedimiento Administrativo General y el reconocimiento del principio de seguridad jurídica.

- La determinación de la obligación tributaria puede ser realizada por el contribuyente o por la Administración Tributaria y tiene como características que es única, integral (teniendo como excepción a las fiscalizaciones parciales) y definitiva. Respecto de las autodeterminaciones, éstas se considerarán definitivas si es que la Administración Tributaria no realiza la revisión y modificación de la misma dentro del plazo de prescripción. Así, una vez que transcurrido el plazo de prescripción, la declaración del contribuyente es inmodificable.

- La prescripción tiene como fundamento al principio de seguridad jurídica; en el caso de la determinación de la obligación tributaria, una vez que transcurra el plazo prescriptorio, no es posible que la Administración Tributaria efectúe una fiscalización y modifique la determinación efectuada por los contribuyentes.

- Existen tres distintas posiciones sobre la posibilidad solicitar información y revisar la determinación de un período prescrito: (i) la Administración Tributaria considera que puede solicitar información y modificar la determinación vinculada con períodos prescritos en la medida que tengan incidencia en períodos no prescritos ; (ii) el Grupo Peruano de la Asociación Fiscal Internacional (IFA) propuso en su oportunidad, que la Administración Tributaria no pueda solicitar información de períodos prescritos si es que estos ya hubiesen sido fiscalizados (permitiendo entonces la modificación de 
períodos prescritos no fiscalizados); y, (iii) nuestra posición, que considera que la prescripción actúa como un límite temporal a la facultad de fiscalización y no es posible solicitar información de un período prescrito $\mathrm{y}$, por ende, no es posible fiscalizar ni determinar la obligación de estos períodos para proyectar sus efectos a ejercicios no prescritos.

- Como consecuencia del término del plazo prescriptorio, la Administración Tributaria pierde la posibilidad de efectuar una nueva determinación de la obligación tributaria, no pudiendo sustentar cualquier modificación en que la prescripción extingue la acción pero no el derecho.

- La prescripción funciona, sin duda alguna, como un límite de carácter temporal a la facultad de fiscalización y determinación de la Administración Tributaria por lo que una vez transcurrido el plazo prescriptorio, no es posible que se emita una Resolución de Determinación.

- En aplicación de las normas vinculadas con la determinación de la obligación tributaria, ésta debe ser efectuada por un acto administrativo idóneo. Así, al no existir acto administrativo alguno, distinto a una Resolución de Determinación, mediante el cual la Administración Tributaria pueda determinar la obligación tributaria, no es posible que ésta sea modificada tratándose de períodos prescritos.

- En nuestra opinión, la obligación tributaria incluye los saldos a favor, pérdidas tributarias y cualquier otro crédito que forme parte de la declaración jurada de los contribuyentes; por ello, la prescripción también alcanza a estos conceptos y no únicamente cuando exista impuesto determinado.

- La jurisprudencia nacional y extranjera no han tenido pronunciamientos uniformes sobre la posibilidad de revisar y reliquidar períodos prescritos; sin embargo, en Argentina y en España sí se cuenta con normas expresas que permiten efectuar la revisión de períodos prescritos aunque sus alcances no generan certeza sobre su aplicación práctica.

- Nuestra recomendación es que se efectúe una modificación al Código Tributario a efectos que la Administración Tributaria solo pueda solicitar información vinculada con ejercicios abiertos a fiscalización (prohibiendo entonces que se solicite 
información de ejercicios prescritos) y, por ende, solo sea posible la modificación de la determinación de períodos no prescritos.

- Otra alternativa posible es adoptar una norma similar a la española en el sentido que bastará con acreditar que las cifras consignadas en períodos no prescritos y que tienen su origen en períodos que ya se encuentran prescritos, son correctas. Para ello, debe confirmarse la importancia del carácter definitivo de las declaraciones juradas y la posibilidad de acreditar cierta información con los libros contables.

- Lo mencionado en las conclusiones anteriores también debe ser aplicado a los casos de saldos a favor, pérdidas tributarias arrastrables y otros créditos por lo que la Administración Tributaria no debería modificar estos conceptos declarados por los contribuyentes en períodos prescritos (y por ende, firmes y definitivos) para proyectar sus efectos a ejercicios no prescritos.
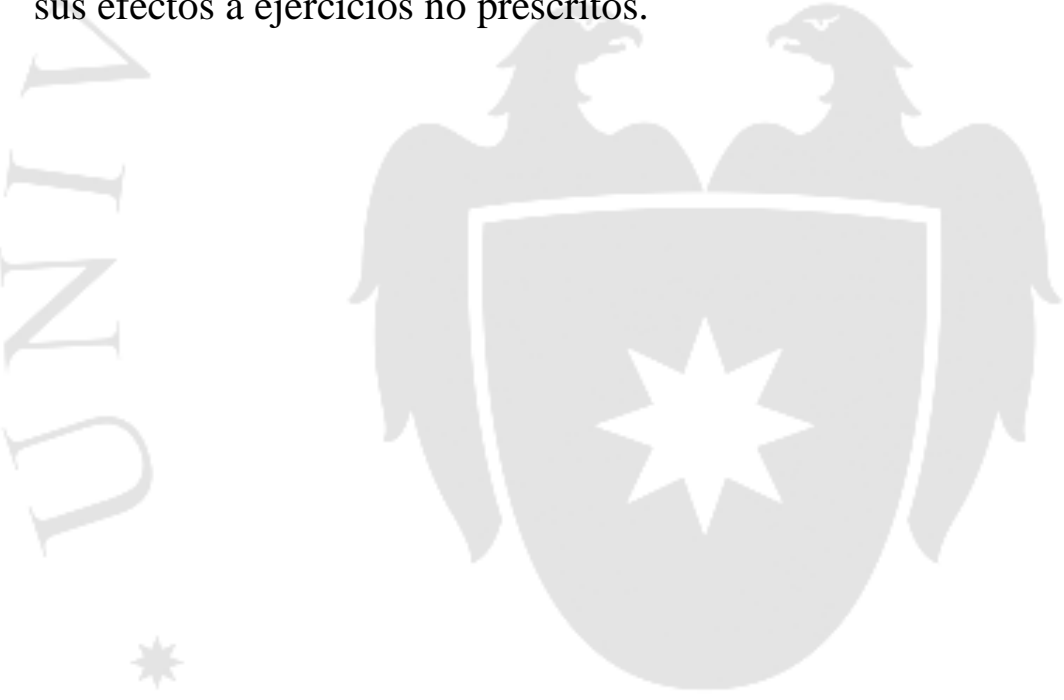


\section{REFERENCIAS}

Bardales Castro, P. (2010). Breves notas sobre los límites constitucionales a la aplicación de presunciones legales en el procedimiento de determinación de la obligación tributaria. En: Lara Márquez, J. (director). Libro Homenaje a Luis Hernández. Berenguel. Lima: Instituto Peruano de Derecho Tributario.

Bocchiardo, J. C. (2003). Derecho Tributario sustantivo o material. En: García Belsunce, Horacio (coordinador). Tratado de Tributación. Tomo I. Volumen 2. Buenos Aires: Editorial Lastrea.

Bravo Cucci, J. (2006). ¿Se puede en una fiscalización tributaria requerir información de períodos prescritos?. En: Derecho virtual. $\mathrm{N}^{\circ} 2$.

Caller Ferreyros, M. E. (2008). La indefinición del plazo de prescripción de la acción de la Administración Tributaria para determinar la Obligación Tributaria. Revista del Instituto Peruano de Derecho Tributario. $\mathrm{N}^{\circ} 46$. Lima.

Castillo Córdova, L. F. (2005). ¿Existen los llamados conflictos entre derechos fundamentales?. Cuestiones Constitucionales 12. México: Universidad Nacional Autónoma de México.

Danós Ordóñez, J. (1994). El Régimen Tributario en la Constitución: Estudio preliminar. Themis. Revista de Derecho. $\mathrm{N}^{\circ} 29$. Lima.

Durán Rojo, L. (2006). La noción del deber constitucional de contribuir. Un estudio introductorio. En: Danós Ordoñez, J. (coordinador). Temas de Derecho Tributario y de Derecho Público. Libro homenaje a Armando Zolezzi Moller. Lima: Palestra Editores.

Fernández Cartagena, J. (2004). Las facultades de Fiscalización y Determinación de la Administración Tributaria. Ponencia presentada en las VIII Jornadas Nacionales de Tributación de la Asociación Fiscal Internacional (IFA). Lima.

Fernández Junquera, M. (2001). La prescripción de la obligación tributaria: un estudio jurisprudencial. Navarra: Editorial Aranzadi.

Gamba Valega, C. (1999). Breves apuntes sobre la discrecionalidad en el Derecho Tributario. Revista del Instituto Peruano de Derecho Tributario. $\mathrm{N}^{\circ} 37$. Lima.

Gamba Valega, C. (2010a). Estado Constitucional de Derecho, sentencias del Tribunal Constitucional y Derecho Tributario. Apuntes para una aproximación necesaria. En: 
Lara Márquez, Jaime (director). Libro Homenaje a Luis Hernández Berenguel. Lima: Instituto Peruano de Derecho Tributario.

Gamba Valega, C. (2010b). Los efectos del Texto Constitucional en el Ordenamiento Tributario. Revista del Instituto Peruano de Derecho Tributario. N $^{\circ}$ 50. Lima.

García Belsunce, H. (2003). Tratado de Tributación. Tomo I. Buenos Aires: Editorial Astrea.

García Novoa, C. (2000). El Principio de seguridad jurídica en materia tributaria. Madrid: Editorial Marcial Pons.

García Novoa, C. (2011a). La incidencia de la doctrina de la solidaridad en cierta jurisprudencia del Tribunal Constitucional peruano en la creación y aplicación de normas fiscales. En: Zavaleta Álvarez, Michael (director). Estudios de Derecho Constitucional Tributario. Lima: Fondo Editorial de la Universidad San Martín de Porres.

García Novoa, César (2011b). Iniciación, interrupción y cómputo del plazo de prescripción de los tributos. Madrid: Editorial Marcial Pons.

Giuliani Fonrouge, C. (2004). Derecho Financiero. Obra actualizada por Susana Navarrine y Rodrigo Asorey. Buenos Aires: Editorial La Ley.

Hernández Berenguel, L. (1990). Modificaciones en el procedimiento de reclamación tributaria: Revista del Instituto Peruano de Derecho Tributario. $\mathrm{N}^{\circ} 19$. Lima

Hernández Berenguel, L. (junio 1992). Prescripción y caducidad. Revista del Instituto Peruano de Derecho Tributario. $\mathrm{N}^{\circ} 22$. Lima.

Hernández Berenguel, L. (diciembre 1998). El término de la fiscalización y la necesaria emisión de Resoluciones de Determinación. Revista Análisis Tributario. Lima: AELE.

Hernández Berenguel, L. (2006). Apuntes para una nueva propuesta sobre prescripción y caducidad de la deuda tributaria. En: Danós Ordoñez, Jorge (coordinador). Temas de Derecho Tributario y de Derecho Público. Libro homenaje a Armando Zolezzi Moller. Lima: Palestra Editores.

Hernández Berenguel, L. (2009). Determinación única, integral y definitiva y determinación parcial. En: Revista Derecho \& Sociedad. $\mathrm{N}^{\circ} 33$. Lima.

Luqui, J. C. (1989). La obligación tributaria. Buenos Aires: Ediciones Depalma. 
Medrano Cornejo, H. (junio 1994). El Principio de Seguridad Jurídica en la creación y aplicación del tributo. Revista del Instituto Peruano de Derecho Tributario. № 26. Lima.

Medrano Cornejo, H. (2005). Límites a la fiscalización: prescripción e intangibilidad de las acotaciones notificadas. En: Ius et Veritas. $\mathrm{N}^{\circ} 31$. Lima.

Navarrine, S. C. (2012). La prescripción de los quebrantos en el Impuesto a las Ganancias. Periódico Económico Tributario. $\mathrm{N}^{\circ}$ 500. Buenos Aires: La Ley.

Pantigoso Velloso Da Silveira, F. (2012). Inequidades y abusos del Derecho en el Código Tributario. En: Defensoría del Contribuyente y Usuario Aduanero. Reflexiones sobre los procedimientos tributarios y aduaneros desde la perspectiva de los derechos de los administrados. Lima: Palestra Editores.

Puig Brutau, J. (1986). Caducidad y Prescripción Extintiva. Barcelona: Editorial Bosch.

Revoredo de Debakey, D. (1985). Código Civil. Volumen VI. Lima: Artes Gráficas de la Industria Avanzada.

Rodríguez Bereijo, Á. (octubre-noviembre de 2008). El Deber de Contribuir como deber constitucional. En: Revista Análisis Tributario. № 248 (Primera parte) y Nº 249 (Segunda parte). Lima: AELE.

Rubio Correa, M. (1987). Prescripción, caducidad y otros conceptos en el nuevo Código Civil. Lima: Fundación M.J. Bustamante de la Fuente.

Rubio Correa, M. (2011). El Test de Proporcionalidad en la Jurisprudencia del Tribunal Constitucional Peruano. Lima: Fondo Editorial de la Pontificia Universidad Católica del Perú.

Talledo Mazú, C. (1987). Manual del Código Tributario. Tomo I. Lima: Editorial Economía y Finanzas.

Terrones López, R. (2010). La discrecionalidad de la Actuación Administrativa: en la búsqueda de un equilibrio. En: Lara Márquez, Jaime (director). Libro Homenaje a Luis Hernández Berenguel. Lima: Instituto Peruano de Derecho Tributario.

Vargas León, L. (junio 1992). Una aproximación al llamado 'diálogo entre la Administración tributaria y el contribuyente'. En: Revista del Instituto Peruano de Derecho Tributario. $\mathrm{N}^{\circ}$ 42. Lima.

Valle Uribe, L. L. (2005). La prescripción extintiva: naturaleza jurídica y los alcances de su interrupción en materia tributaria. En: Revista del Instituto Peruano de Derecho Tributario. $\mathrm{N}^{\circ}$ 43. Lima. 
Vidal Ramírez, F. (1985). La prescripción y la caducidad en el Código Civil Peruano. Lima: Editorial Cultural Cuzco.

Villegas Lévano, C. (2011). El Respeto a los Derechos Fundamentales en el ejercicio de las facultades discrecionales de la Administración Tributaria. En: Zavaleta Álvarez, Michael (director). Estudios de Derecho Constitucional Tributario. Lima: Fondo Editorial de la Universidad San Martín de Porres.

Villegas, H. (2002). Curso de Finanzas, Derecho Financiero y Tributario. Buenos Aires: Editorial Astrea. 